\title{
Horizontal and Vertical Structure of Easterly Waves in the Pacific ITCZ
}

\author{
Yolande L. SerRa \\ The University of Arizona, Tucson, Arizona \\ GeORge N. KILAdis \\ NOAA/ESRL Physical Sciences Division, Boulder, Colorado \\ Meghan F. CRONIN \\ NOAA/Pacific Marine Environmental Laboratory, Seattle, Washington
}

(Manuscript received 8 November 2006, in final form 27 June 2007)

\begin{abstract}
Outgoing longwave radiation (OLR) and low-level wind fields in the Atlantic and Pacific intertropical convergence zone (ITCZ) are dominated by variability on synoptic time scales primarily associated with easterly waves during boreal summer and fall. This study uses spectral filtering of observed OLR data to capture the convective variability coupled to Pacific easterly waves. Filtered OLR is then used as an independent variable to isolate easterly wave structure in wind, temperature, and humidity fields from open-ocean buoys, radiosondes, and gridded reanalysis products. The analysis shows that while some Pacific easterly waves originate in the Atlantic, most of the waves appear to form and strengthen within the Pacific. Pacific easterly waves have wavelengths of $4200-5900 \mathrm{~km}$, westward phase speeds of $11.3-13.6 \mathrm{~m} \mathrm{~s}^{-1}$, and maximum meridional wind anomalies at about $600 \mathrm{hPa}$. A warm, moist boundary layer is observed ahead of the waves, with moisture lofted quickly through the troposphere by deep convection, followed by a cold, dry signal behind the wave. The waves are accompanied by substantial cloud forcing and surface latent heat flux fluctuations in buoy observations. In the central Pacific the horizontal structure of the waves appears as meridionally oriented inverted troughs, while in the east Pacific the waves are oriented southwestnortheast. Both are tilted slightly eastward with height. Although these tilts are consistent with adiabatic barotropic and baroclinic conversions to eddy energy, energetics calculations imply that Pacific easterly waves are driven primarily by convective heating. This differs from African easterly waves, where the barotropic and baroclinic conversions dominate.
\end{abstract}

\section{Introduction}

The atmosphere in the Pacific and Atlantic ITCZ is dominated by convectively coupled propagating waves on synoptic time scales. Westward-propagating synoptic disturbances include easterly waves (Chang 1970; Reed and Recker 1971; Reed et al. 1977; Nitta et al. 1985; Tai and Ogura 1987; Lau and Lau 1990; Gu and Zhang 2002; Serra and Houze 2002; Petersen et al. 2003), as well as mixed Rossby-gravity (MRG) modes (e.g., Yanai et al. 1968; Hayashi 1970; Liebmann and

Corresponding author address: Yolande L. Serra, Department of Atmospheric Science, The University of Arizona, 1118 E. 4th St., Box 210081, Tucson, AZ 85721-0081.

E-mail: serra@atmo.arizona.edu
Hendon 1990; Takayabu and Nitta 1993; Dunkerton and Baldwin 1995; Dickinson and Molinari 2002). Eastward-propagating Kelvin waves also have a large influence on convection over these ocean basins (Takayabu and Murakami 1991; Dunkerton and Crum 1995; Straub and Kiladis 2002, 2003; Mounier et al. 2007), along with the lower-frequency Madden-Julian oscillation (MJO; e.g., Madden and Julian 1994; Maloney and Hartmann 2000; Zhang 2005). The purpose of the present study is to reexamine the statistical structure of Pacific easterly waves in data sources such as radiosondes, outgoing longwave radiation (OLR), and reanalysis, along with their signals in open-ocean buoys using spectrally filtered OLR to isolate the wave structures.

Early observations of easterly waves in the Pacific 
and West African-east Atlantic regions indicate that they have wavelengths of $2500-3500 \mathrm{~km}$, westward phase speeds of $8 \mathrm{~m} \mathrm{~s}^{-1}$, periods of 3-4 days, and maximum meridional wind anomalies at $700-850 \mathrm{hPa}$ (Reed and Recker 1971; Burpee 1972; Reed et al. 1977; Thompson et al. 1979). Wave characteristics and phasing with convection vary with latitude and between land and ocean regions in the West African/east Atlantic region (Reed et al. 1977; Lau and Lau 1990, 1992; Diedhiou et al. 2001, 2002; Kiladis et al. 2006). Studies of Pacific easterly waves also find variations in wave characteristics as a function of longitude (Reed and Recker 1971; Serra and Houze 2002; Petersen et al. 2003; Tam and $\mathrm{Li}$ 2006). Much of the structural change observed in the Pacific waves is attributed to variations in the background mean vertical wind shear across the Pacific (Holton 1971; Reed and Recker 1971). Horizontal and vertical wind shear is an additional influence on the structure of African easterly waves (e.g., Norquist et al. 1977; Hsieh and Cook 2005, 2007).

Over West Africa and the east Atlantic, barotropic and baroclinic instabilities brought on by a reversal of the meridional potential vorticity gradient within the African Easterly Jet (AEJ), as well as a strong meridional surface temperature gradient, are the generally accepted mechanisms for the initiation of easterly waves in this region (e.g., Norquist et al. 1977; Thorncroft and Hoskins 1994a,b; Hsieh and Cook 2005, 2007; Hall et al. 2006). Ferreira and Schubert (1997) and Wang and Magnusdottir (2005) suggest that barotropic instability of the ITCZ resulting from vorticity anomalies related to ITCZ convection might play a role in easterly wave formation and tropical cyclogenesis in the east Pacific. Other studies suggest that easterly waves in the east Pacific originate over Africa and rejuvenate in the Caribbean and east Pacific regions because of instabilities in the mean easterly flow brought on by reversals in the background meridional potential vorticity gradient in these regions (Molinari et al. 1997; Molinari and Vollaro 2000). Maloney and Hartmann (2001) find that low-level westerly periods related to the MJO enhance barotropic growth of eddies on submonthly time scales in the east Pacific, Gulf of Mexico, and over Central America, providing a more favorable environment for the growth of synoptic disturbances and hurricanes. These authors further suggest that waves propagating from the Caribbean into the east Pacific could be rejuvenated during a westerly phase of the MJO, as well as possibly formed in situ in these regions.

This study focuses on obtaining a statistical representation of easterly wave structure in the Pacific ITCZ for the June-November season, when the waves are most active, and compares these structures in the eastern and central-western Pacific. A detailed statistical analysis of Pacific easterly waves across the basin has not yet been available to compare with the much more extensively studied waves over the Atlantic and Africa. A thorough documentation of these waves is a first step toward further understanding of the role of easterly waves in the maintenance of the ITCZ and in tropical storm formation over the Pacific.

\section{Data and methods}

The in situ data used for this study are provided by the Tropical Atmosphere Ocean (TAO)/Triangle Trans-Ocean Buoy Network (TRITON) buoy array and the TAO/East Pacific Investigation of Climate (EPIC) buoys in the eastern tropical Pacific, along with radiosonde data from the Integrated Global Radiosonde Archive (IGRA), obtained from the National Oceanic and Atmospheric Administration (NOAA) National Climatic Data Center (NCDC). The TAO/ TRITON array comprises nearly 70 buoys at 10 lines between $138^{\circ} \mathrm{E}$ and $95^{\circ} \mathrm{W}$, with seven standard sites along each line from $8^{\circ} \mathrm{S}$ to $8^{\circ} \mathrm{N}$ (McPhaden et al. 1998). Each buoy in the array measures air temperature, relative humidity, surface winds, and ocean temperatures from 1- to 500-m depth. Figure 1 shows only those buoys from the TAO/TRITON array used for this study.

In addition, our analysis relies upon meteorological data from the buoys deployed along $95^{\circ} \mathrm{W}$ at $3.5^{\circ}, 10^{\circ}$, and $12^{\circ} \mathrm{N}$ in support of the EPIC experiment (Cronin et al. 2002) (Fig. 1). EPIC enhancements to TAO began in late 1999 and ended in late 2003. Although the EPIC buoy study period is limited to June-November 200003 , our overall study period for the buoys in the TAO/ TRITON array is June-November 1990-2003.

The TAO/TRITON and TAO/EPIC moorings provide high-resolution, quality controlled data at anywhere from $10 \mathrm{~min}$ to hourly, depending on the type of mooring recording the data. Buoy data are particularly valuable for the estimation of surface fluxes, where reanalyses have been shown to exhibit substantial biases (Jiang et al. 2005; Cronin et al. 2006b). We smooth all high-resolution buoy measurements with greater-thanhourly resolution to hourly using a 2-h hanning window. The resulting hourly time series are used for all subsequent calculations involving buoy data in this study.

The IGRA dataset contains quality controlled radiosonde observations from several Micronesian Islands well suited for the study of waves over the central to western Pacific, as demonstrated in many past studies (e.g., Yanai et al. 1968; Reed and Recker 1971). Here, 

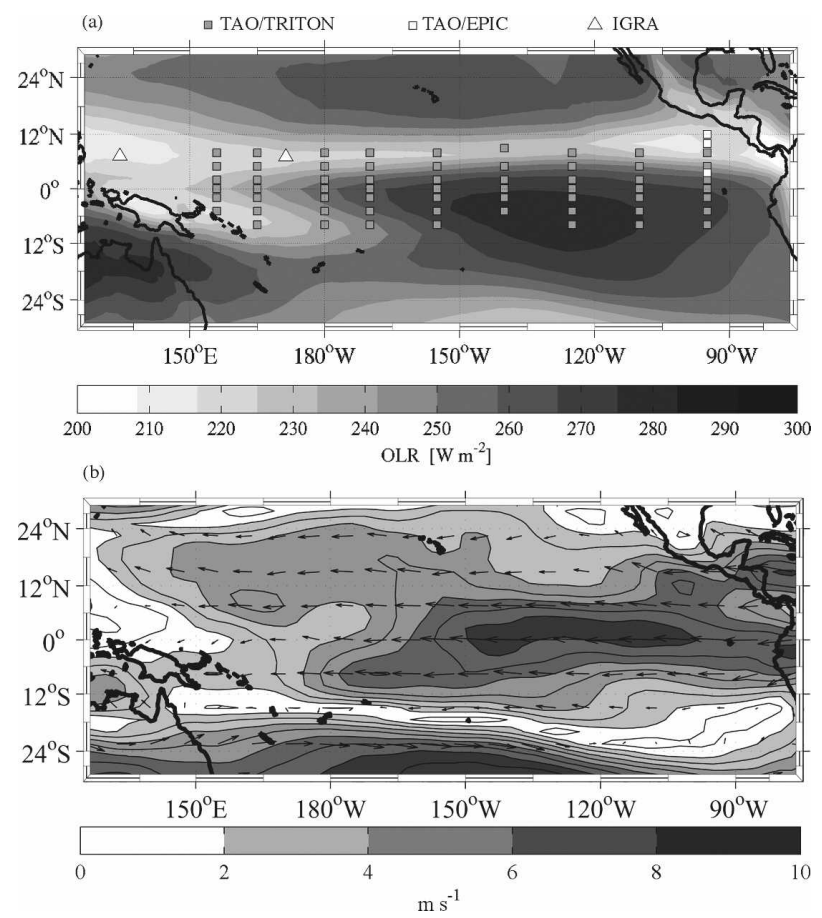

FIG. 1. June-November 1979-2002 (a) TAO/TRITON and TAO/EPIC buoys and IGRA stations used for this study overlaid on OLR and (b) NCEP-NCAR 700-hPa wind speed (contours) and wind vectors (arrows).

we utilize wind, temperature, and specific humidity data available at $50-\mathrm{hPa}$ resolution from Koror $\left(7.3^{\circ} \mathrm{N}\right.$, $\left.134.5^{\circ} \mathrm{E}\right)$ and Majuro $\left(7.1^{\circ} \mathrm{N}, 171.4^{\circ} \mathrm{E}\right)$, the most western and eastern Micronesian Islands, respectively. These data provide a detailed view of the vertical structure of easterly waves across the Micronesian region.

To document the structure of synoptic disturbances across the Pacific ITCZ, we also analyze NOAA OLR and the National Centers for Environmental Prediction-National Center for Atmospheric Research (NCEP-NCAR) reanalysis winds, temperatures, and humidities for June-November 1979-2002 following the method of Wheeler et al. (2000). Easterly waves can be effectively isolated through space-time filtering of OLR following the methodology of Wheeler and Kiladis (1999), who found spectral peaks corresponding to easterly waves [the tropical disturbance (TD) band; see their Fig. 5]. An advantage of using OLR as a basis to isolate the kinematic fields associated with the wave is that we rely on a more directly observed quantity rather than the reanalyses for determining the location, time period, and intensity of easterly wave activity. The space-time region we use as a filter in the study is shown in Fig. 1 of Kiladis et al. (2006), and basically includes fluctuations between 2 and 6 days in westwardmoving zonal wavenumbers more than 6 . We linearly regress unfiltered daily averaged OLR, IGRA, and NCEP-NCAR fields onto TD-filtered OLR time series at select locations ("base points") to obtain statistical representations of their vertical and horizontal structure related to easterly waves. TAO data are first smoothed to 6-hourly, matching the NCEP-NCAR reanalyses time resolution. Both datasets are then subsampled at 0600 and 1800 UTC for regressing onto twice-daily OLR data. Statistical significance is assessed through a standard $t$ test once the degrees of freedom are determined from the autocorrelation characteristics of both the predictor and predictand. For a more complete description of this technique we refer the reader to the above references, and in particular to Kiladis et al. (2006), who apply this technique to study Atlantic and African easterly waves.

\section{Climatology of the tropical Pacific during boreal summer and fall}

OLR and NCEP-NCAR 700-hPa wind climatologies for June-November 1979-2002 are shown in Figs. 1a,b, respectively. A band of minimum OLR is centered at roughly $7.5^{\circ} \mathrm{N}$ across the Pacific basin marking the ITCZ. The 700-hPa wind vectors are easterly in the mean throughout the tropical latitudes at this time, with wind speeds exceeding $8 \mathrm{~m} \mathrm{~s}^{-1}$ within the main maximum across the eastern and central Pacific. A second wind maximum is observed in the Caribbean Sea centered at about $15^{\circ} \mathrm{N}$ where the Caribbean jet is evident. This feature is strongest from June to September with maximum seasonal mean wind speeds of about 10 $\mathrm{m} \mathrm{s}^{-1}$. The envelope of maximum wind continues across Central America into the eastern Pacific, with distinctive minima observed on the leeward side of the Sierra Madre and Andes Mountain ranges.

Profiles of NCEP-NCAR zonal winds from $10^{\circ} \mathrm{S}$ to $20^{\circ} \mathrm{N}$ along $95^{\circ} \mathrm{W}$ and $172.5^{\circ} \mathrm{E}$, as well as a longitudinal cross section from $120^{\circ} \mathrm{E}$ to $60^{\circ} \mathrm{W}$ along $7.5^{\circ} \mathrm{N}$ are shown in Fig. 2. At $95^{\circ} \mathrm{W}$ (Fig. 2a), two easterly wind maxima between roughly the equator and $10^{\circ} \mathrm{N}$ are evident, one at $700 \mathrm{hPa}$ and another stronger one at 200 $\mathrm{hPa}$. Strong easterly shear is observed below $700 \mathrm{hPa}$ as well as above $200 \mathrm{hPa}$ at the latitudes of these maxima. At $172.5^{\circ} \mathrm{E}$ (Fig. 2b), the easterly maximum tilts equatorward with height, with the near-surface maximum at $15^{\circ} \mathrm{N}$ shifting upward to $400 \mathrm{hPa}$ at the equator. Weak shear is evident throughout the troposphere south of $10^{\circ} \mathrm{N}$ at this location. The longitudinal cross section at the latitude of the ITCZ in Fig. 2c indicates that the greatest vertical shear in the zonal winds is in the east Pacific at $150 \mathrm{hPa}$ where westerly shear is observed, and at $850 \mathrm{hPa}$ where easterly shear is observed. Strong westerly shear is also observed in the far western por- 
(a)

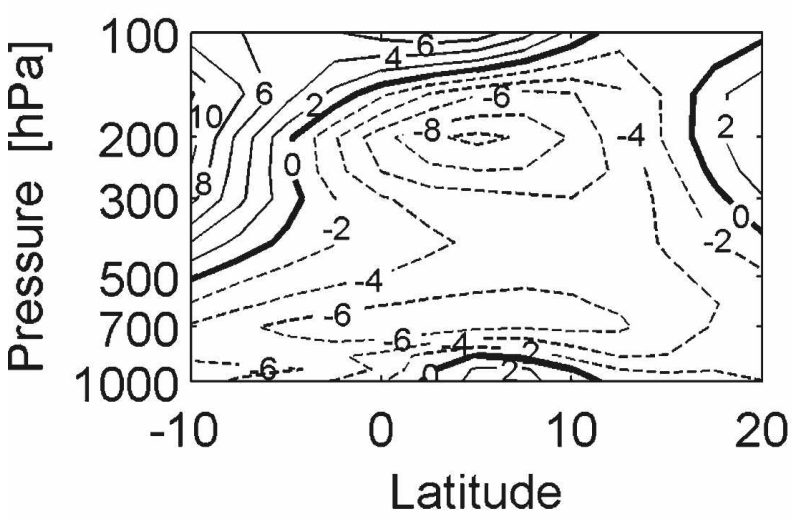

(b)

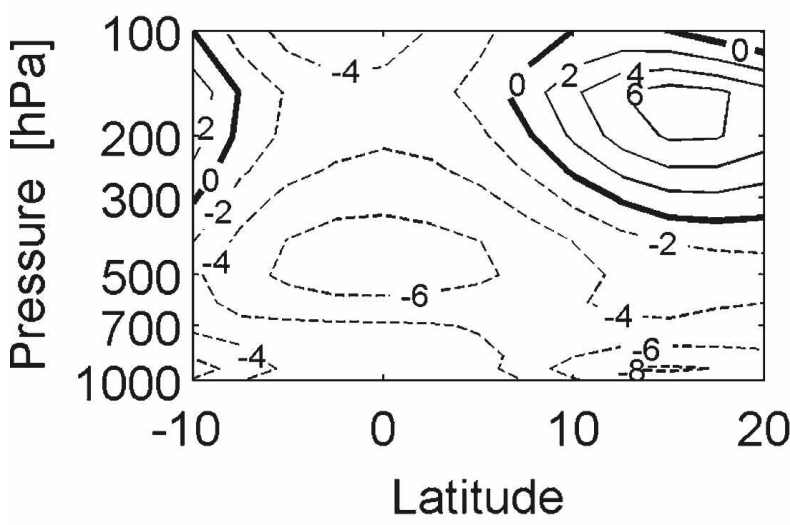

(c)

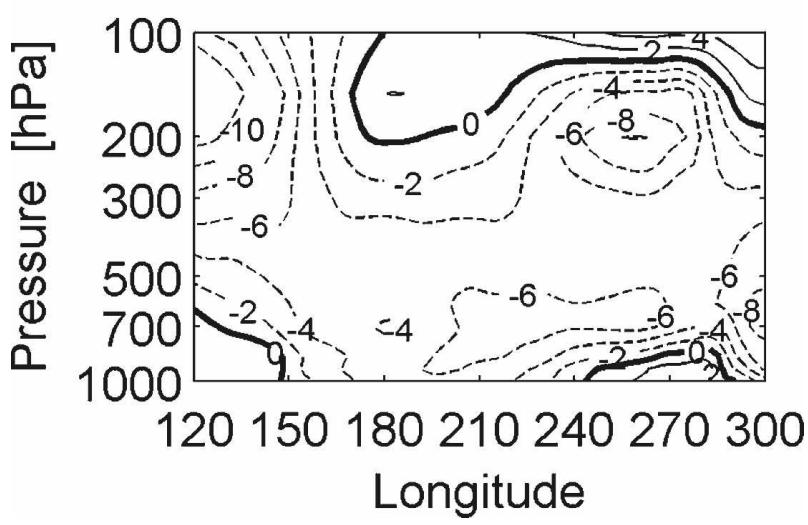

FIG. 2. Vertical profiles of NCEP-NCAR zonal winds for JuneNovember $1979-2002$ from $10^{\circ} \mathrm{S}$ to $20^{\circ} \mathrm{N}$ along (a) $95^{\circ} \mathrm{W}$ and (b) $172.5^{\circ} \mathrm{E}$, as well as (c) a profile of zonal winds from $120^{\circ} \mathrm{E}$ to $60^{\circ} \mathrm{W}$ along $7.5^{\circ} \mathrm{N}$. Contours are at $2 \mathrm{~m} \mathrm{~s}^{-1}$ intervals. Positive contours are solid lines; negative contours are dashed lines.

tion of the basin west of $150^{\circ} \mathrm{E}$ in the midtroposphere. Background mean wind profiles have been shown to affect the structure of easterly waves (Holton 1971). The tilt of the wave structure with respect to the mean wind profiles also indicates the direction of kinetic energy transfer between the waves and the mean flow.
Further discussion of the mean zonal wind fields in relation to the observed easterly wave structure will be presented in later sections.

\section{Surface variability on synoptic time scales in the tropical Pacific}

\section{a. Seasonal cycle}

Seasonal analyses of TD-filtered OLR variance indicate that the easterly wave activity is at a maximum during boreal summer and fall seasons (Roundy and Frank 2004). This is evident in Fig. 3, which shows the standard deviations of twice-daily TD-filtered OLR throughout the tropical Pacific for each 3-month season. The seasonal cycle of easterly wave activity mirrors the annual cycle of mean convection over the Pacific (e.g., Mitchell and Wallace 1992), with a peak amplitude in Northern Hemisphere summer and fall. Thus, we focus our analysis of synoptic variability in the tropical east Pacific within the June-November time period. Here, $20 \mathrm{~W} \mathrm{~m}^{-2}$ is used as a representative perturbation in the TD-filtered OLR anomaly, a typical value for an unfiltered easterly wave over the Pacific.

\section{b. TAO buoy spectral results}

To examine surface synoptic variability in the Pacific, we have computed the power spectral density for the TAO/TRITON buoy surface data at $5^{\circ}$ and $8^{\circ} \mathrm{N}$ from $156^{\circ} \mathrm{E}$ to $95^{\circ} \mathrm{W}$ for June-November $1990-2003$. A more detailed comparison between buoy spectra and those obtained from various reanalyses datasets is presented by Serra et al. (2007), and shows that reanalyses do a reasonable job of capturing Pacific surface variability on synoptic time scales. The power spectral density is calculated using the Welch periodogram method with $50 \%$ overlap on 120 -day segments of hourly buoy data. Power spectral estimates for each June-November period are then averaged together over all years to obtain the mean and standard deviation of the power spectral density for each variable, where the degrees of freedom are assumed to be one less than the total number of 120-day segments.

The June-November power spectral density of meridional and zonal wind, air temperature, and specific humidity for the TAO/TRITON moorings are shown in Fig. 4. The vertical gray lines in each plot bracket variability on 3-6-day time periods. The power spectra are plotted in variance-preserving format so that the area under the curve represents the variance at a given period. The 3-6-day period explains $30 \%$ of the variance in the meridional and $15 \%$ of the variance in the zonal winds out to 120 days, (Figs. 4a,b). Also evident are the diurnal and semidiurnal peaks in the wind components. 
(a)

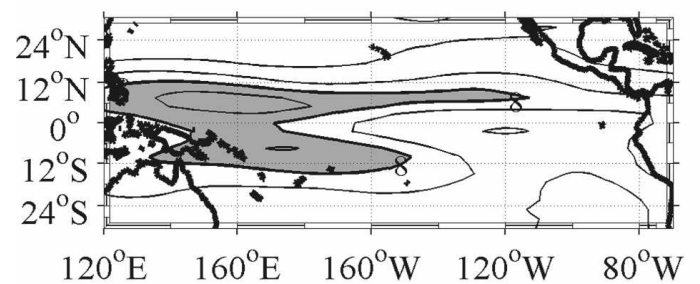

(c)

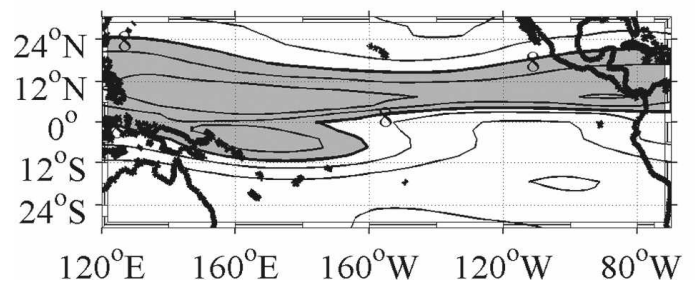

(b)

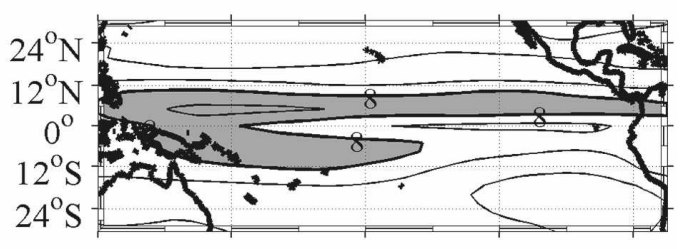

(d)

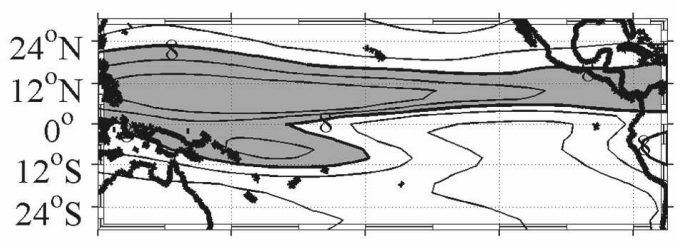

$120^{\circ} \mathrm{E} \quad 160^{\circ} \mathrm{E} \quad 160^{\circ} \mathrm{W} \quad 120^{\circ} \mathrm{W} \quad 80^{\circ} \mathrm{W}$

FIG. 3. Std dev of TD-filtered OLR 1979-2002 for (a) December-February (DJF), (b) March-May (MAM), (c) June-August (JJA), and (d) September-November (SON). Contour interval is $2 \mathrm{~W} \mathrm{~m}^{-2}$.

(a)

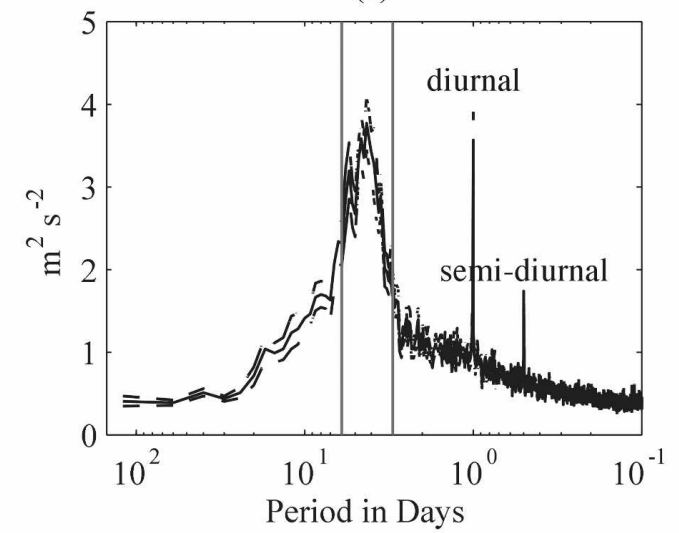

(c) 2.40 .5

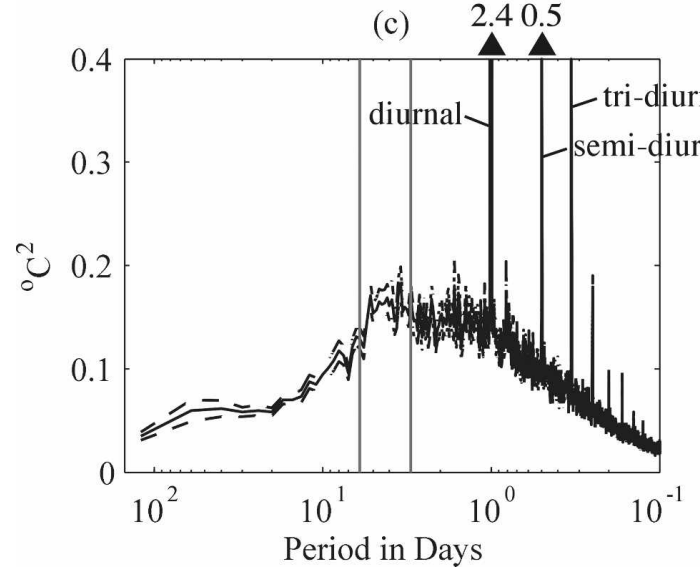

(b)

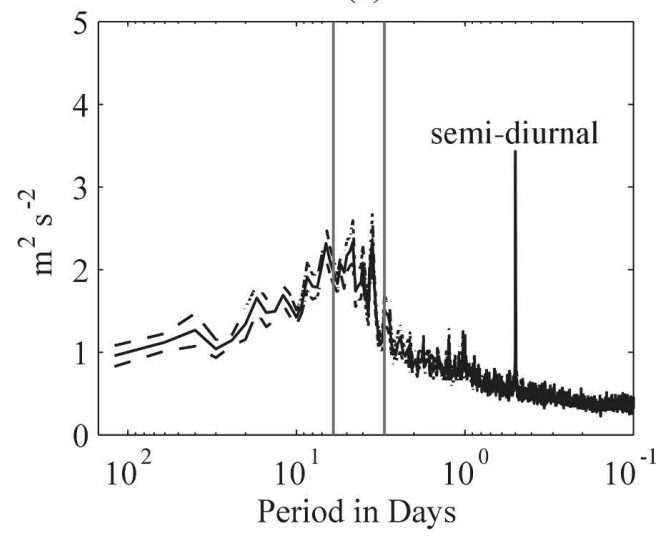

(d)

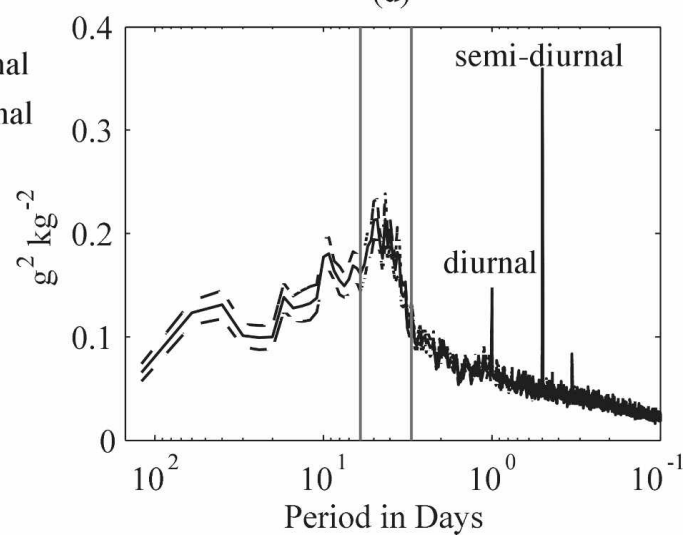

FIG. 4. Power spectral density of (a) meridional wind, (b) zonal wind, (c) air temperature, and (d) specific humidity shown in variance-preserving format using data from TAO/TRITON buoys between $156^{\circ} \mathrm{E}$ and $95^{\circ} \mathrm{W}$ along $5^{\circ}$ and $8^{\circ} \mathrm{N}$ in the Pacific. Gray vertical lines indicate 3- and 6-day periods. Dashed lines contain $95 \%$ of the data or two std dev. Values of the temperature peaks at the diurnal and semidiurnal periods are indicated above the black triangles in (c). 
The diurnal peak is most prominent in the meridional winds, while the semidiurnal peak dominates the zonal winds in agreement with Deser and Smith (1998). As the mean flow tends to be zonal in this region, the zonal winds tend to have more power at lower frequencies than the meridional winds.

The 3-6-day period explains $15 \%$ of the variance in temperature out to 120 days. The diurnal and semidiurnal peaks are more prominent but together explain less then $1 \%$ of the total variance over this time period. The values above the arrowheads in this plot denote the power for these peaks, which is outside the upper range of the graph. The energy on synoptic time scales for temperature tends to cascade toward shorter time-scale variability, in contrast to the energy on synoptic time scales for the wind components, which appears as welldefined spectral peaks. The physical basis, if any, for the large tridiurnal peak at $8 \mathrm{~h}$ and subsequent peaks on shorter time scales has not yet been investigated.

The variance in specific humidity is shown in Fig. 4d. As with the winds and temperature, the synoptic signal is the largest fraction of the total variance in humidity up to 120 days, explaining $17 \%$ of the variance over this time period. These data also indicate significant diurnal and semidiurnal humidity variance, with the semidiurnal peak being more prominent than the diurnal peak. At lower frequencies, the humidity spectrum indicates small peaks at 10 days, 17 days, and roughly 50 days. These low-frequency peaks are also observed to a lesser extent in the zonal wind data (Fig. 4b). Equatorial Kelvin or Rossby waves may explain the 10- and 17-day variability (Kiladis and Wheeler 1995), while the MJO likely accounts for the broad peak centered at 50 days. The power spectra of buoy wind, temperature, and humidity data shown in Fig. 4 demonstrate that synoptic time scales dominate the variability in the Pacific ITCZ during June-November. It is important to recognize that, along with easterly waves, MRG waves also contribute substantially to the variability over the Pacific in the 3-6-day-period range (e.g., Liebmann and Hendon 1990; Wheeler et al. 2000; Roundy and Frank 2004), but these waves are easily eliminated by the space-time filtering approach employed in this study.

\section{c. Easterly wave surface variability}

To determine the phase relationships between easterly waves and surface parameters from the buoys, we regress buoy meridional wind, air temperature, specific humidity, and latent heat flux at $10^{\circ} \mathrm{N}, 95^{\circ} \mathrm{W}$ and $8^{\circ} \mathrm{N}$, $165^{\circ} \mathrm{E}$ onto TD-filtered OLR at $10^{\circ} \mathrm{N}, 95^{\circ} \mathrm{W}$ and $7.5^{\circ} \mathrm{N}$, $165^{\circ} \mathrm{E}$, respectively. Figure 5 shows time-lagged regressions of these variables for both base points, as well as time-lagged regressions of OLR, all scaled to an OLR perturbation of $-20 \mathrm{~W} \mathrm{~m}^{-2}$. The sign convention for latent heat flux is such that a negative anomaly implies enhanced evaporation from the ocean. Because of the additional measurements provided by the TAO/EPIC buoys (Cronin et al. 2006a), we also show time-lagged regressions of longwave cloud forcing, shortwave cloud forcing, and rain rate for the $95^{\circ} \mathrm{W}$ location (Fig. 5c). Cloud forcing is calculated as the cloudy minus clear sky radiation at the surface (Cronin et al. 2006a).

At both $10^{\circ} \mathrm{N}, 95^{\circ} \mathrm{W}$ and $8^{\circ} \mathrm{N}, 165^{\circ} \mathrm{E}$, the regressions show that a day or so in advance of the minimum in OLR, anomalously warm and humid conditions within northerlies are seen, followed by anomalously high (more cooling) surface latent heat flux coincident with the OLR minimum. As the wave passes, the winds shift to anomalously southerly with cool and dry conditions. The additional measurements at $95^{\circ} \mathrm{W}$ show that maximum cloudiness and rainfall are associated with the OLR minimum. Indeed, the radiometer measurements indicate that cloud forcing, probably due to low stratiform, continues for several days beyond the OLR minimum, consistent with Petersen et al.'s (2003) observations during the EPIC field campaign. While these measurements do not permit a quantitative estimate of the precipitation and evaporation terms associated with easterly waves, the observed precipitation anomalies are an order of magnitude larger than the moisture flux anomalies suggesting moisture convergence is important to the maintenance of the convection coupled to the waves.

The primary difference between the two sites is that the near-surface cooling lags the OLR minimum by a day at $10^{\circ} \mathrm{N}, 95^{\circ} \mathrm{W}$, while it is in phase with it at $8^{\circ} \mathrm{N}$, $165^{\circ} \mathrm{E}$. In addition, the magnitudes of the moistening and latent heat flux anomalies are greater at $10^{\circ} \mathrm{N}$, $95^{\circ} \mathrm{W}$ than at $8^{\circ} \mathrm{N}, 165^{\circ} \mathrm{E}$. Otherwise, the wave structure is remarkably similar at these locations.

Time-longitude diagrams of the meridional wind anomalies across the TAO array for the $10^{\circ} \mathrm{N}, 95^{\circ} \mathrm{W}$ base point (not shown) indicate phase speeds of about $-13.6 \mathrm{~m} \mathrm{~s}^{-1}$ and wavelengths of about $5900 \mathrm{~km}$ (Table 1). Using a similar diagram, the estimated phase speed for the base point at $7.5^{\circ} \mathrm{N}, 165^{\circ} \mathrm{E}$ is $-12.2 \mathrm{~m} \mathrm{~s}^{-1}$ and the estimated wavelength is $4600 \mathrm{~km}$ (Table 1). Thus, the waves at $165^{\circ} \mathrm{E}$ are slower and shorter than those farther east. This is investigated further in the next section.

\section{Horizontal eddy structure}

We use the base points at $10^{\circ} \mathrm{N}, 95^{\circ} \mathrm{W}$ and $7.5^{\circ} \mathrm{N}$, $172.5^{\circ} \mathrm{E}$ to study the horizontal structure of easterly waves in the NCEP-NCAR reanalyses. The $172.5^{\circ} \mathrm{E}$ 
(a)

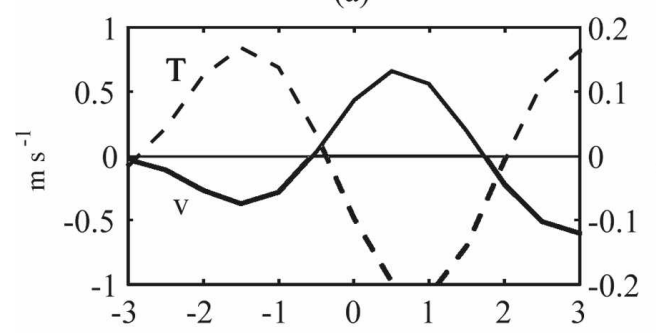

(b)

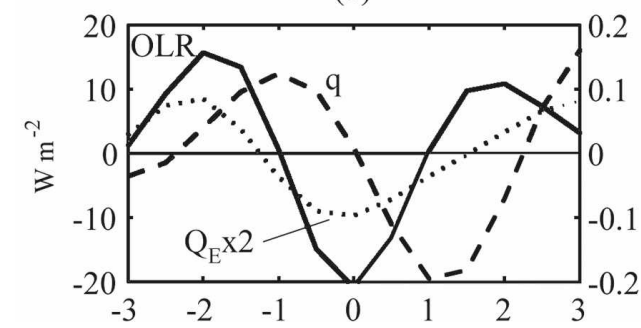

(c)

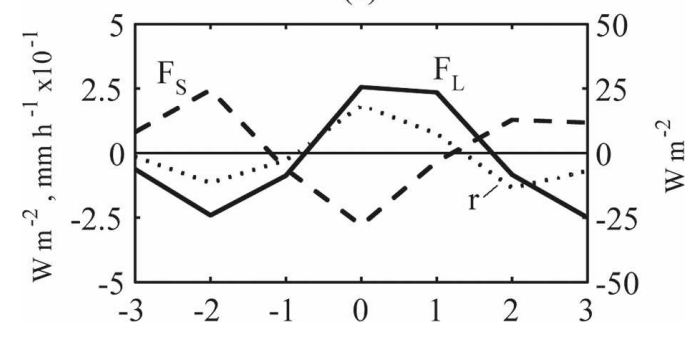

(d)

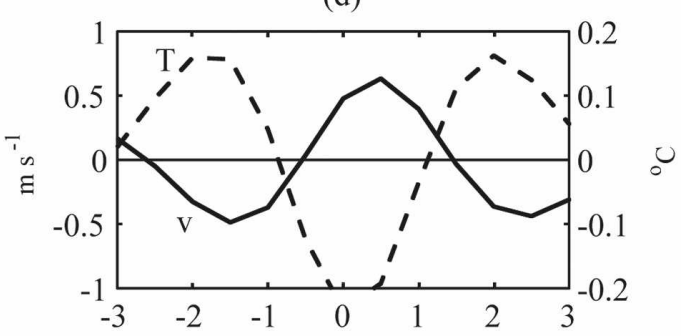

(e)

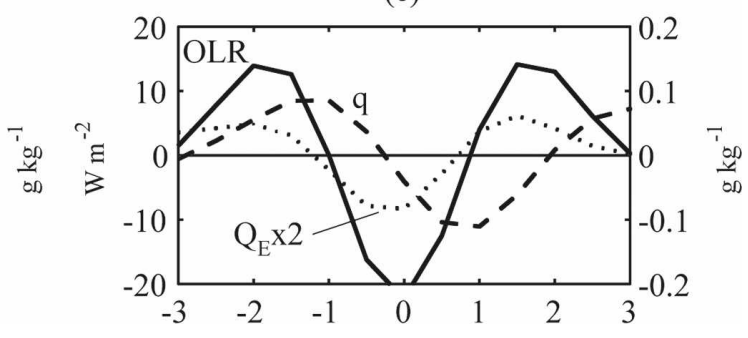

FIG. 5. Regressions of buoy (a) meridional wind (solid; $v$ ) and air temperature (dashed; $T$ ); (b) specific humidity (dashed; $q$ ) and latent heat flux (dotted; $Q_{E}$ ); and (c) longwave cloud forcing (left axis; solid; $F_{L}$ ), shortwave cloud forcing (right axis; dashed; $F_{S}$ ), and rain rate (dotted; $r$ ) all at $10^{\circ} \mathrm{N}, 95^{\circ} \mathrm{W}$. Also shown in (b) is TD-filtered OLR at $10^{\circ} \mathrm{N}, 95^{\circ} \mathrm{W}$ (solid; OLR). (d), (e) Same as (a), (b) but for buoy at $8^{\circ} \mathrm{N}, 165^{\circ} \mathrm{E}$ using an OLR base point at $7.5^{\circ} \mathrm{N}, 165^{\circ} \mathrm{E}$. Here $Q_{E}$ has been multiplied by 2 to better match the range of OLR values.

maining 13, 10 were traced back to African easterly waves while the other 3 were traced back to easterly waves in the Caribbean.

From Fig. 6a, the phase speed of the convective signal over the eastern Pacific is estimated to be around $-10.5 \mathrm{~m} \mathrm{~s}^{-1}$, with a wavelength of $3300 \mathrm{~km}$ (Table 2), similar to the scales obtained by Reed and Recker (1971), Tai and Ogura (1987), and Takayabu and Nitta (1993). A similar diagram for 700-hPa meridional wind regressions (not shown) indicates the kinematic signal has a phase speed of $-11.3 \mathrm{~m} \mathrm{~s}^{-1}$, with a wavelength of $4400 \mathrm{~km}$, somewhat faster and longer than the convective structure (Table 2). These values can be compared to those calculated from the buoy surface wind anomalies and indicate that the NCEP-NCAR wave structure

TABLE 1. TD-wave characteristics derived from TAO buoy meridional surface winds regressed onto TD-filtered OLR at indicated base points. The longitudes of the base points used for the buoy regressions are chosen to match buoy locations.

\begin{tabular}{cccc}
\hline \hline $\begin{array}{c}\text { Base point } \\
(\text { buoy location })\end{array}$ & $\begin{array}{c}\text { Phase speed } \\
\left(\mathrm{m} \mathrm{s}^{-1}\right)\end{array}$ & $\begin{array}{c}\text { Wavelength } \\
(\mathrm{km})\end{array}$ & $\begin{array}{c}\text { Period } \\
(\text { days })\end{array}$ \\
\hline $10^{\circ} \mathrm{N}, 95^{\circ} \mathrm{W}\left(10^{\circ} \mathrm{N}, 95^{\circ} \mathrm{W}\right)$ & -13.6 & 5900 & 5.1 \\
$7.5^{\circ} \mathrm{N}, 165^{\circ} \mathrm{E}\left(8^{\circ} \mathrm{N}, 165^{\circ} \mathrm{E}\right)$ & -12.2 & 4600 & 4.4 \\
\hline
\end{tabular}


(a)

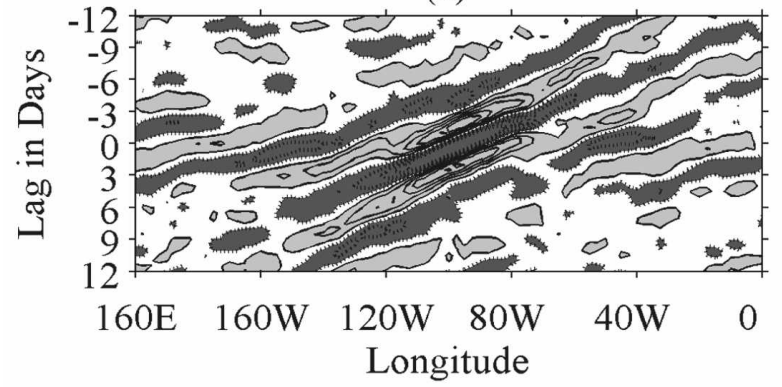

(b)

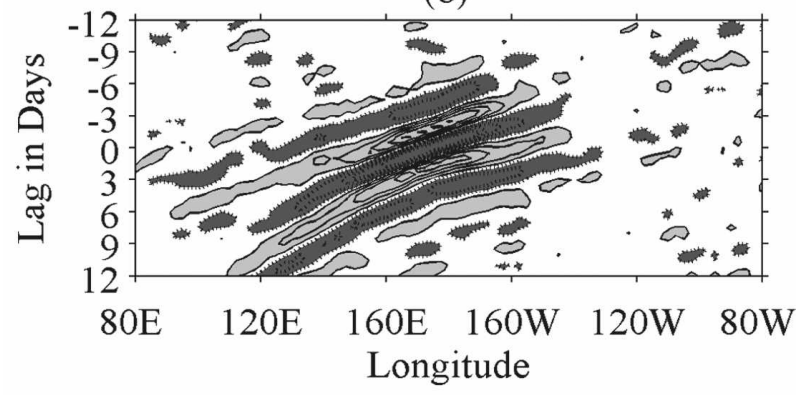

(c)



FIG. 6. Hovmoeller diagram of OLR regressions averaged from $7.5^{\circ}$ to $12.5^{\circ} \mathrm{N}$ for the base points at (a) $10^{\circ} \mathrm{N}, 95^{\circ} \mathrm{W}$ and (b) $7.5^{\circ} \mathrm{N}$, $172.5^{\circ} \mathrm{E}$. Dark gray contours are negative anomalies; lighter gray contours are positive anomalies. Contour lines are drawn at intervals of $2 \mathrm{~W} \mathrm{~m}^{-2}$ starting at $\pm 1 \mathrm{~W} \mathrm{~m}^{-2}$. (c) Hovmoeller of TD-filtered OLR averaged from $7.5^{\circ}$ to $12.5^{\circ} \mathrm{N}$ for dates shown in 2001. Contour shading starts at $240 \mathrm{~W} \mathrm{~m}^{-2}$. TD-filtered OLR contour is at $-8 \mathrm{~W} \mathrm{~m}^{-2}$. Black bar along abscissa near $80^{\circ} \mathrm{W}$ indicates location of Central America at $10^{\circ} \mathrm{N}$.

at $700 \mathrm{hPa}$ is in between the slower, shorter structure reported by Serra and Houze (2002) and the faster, longer structure estimated from the buoy surface winds (Table 1). The characteristics of the central Pacific waves are very similar although with a slightly longer convective wavelength and slightly shorter kinematic wavelength (Tables 1,2 ). As they propagate into the western Pacific (west of $150^{\circ} \mathrm{E}$ ), their phase speeds slow to near $-6 \mathrm{~m} \mathrm{~s}^{-1}$ and their wavelengths decrease to around $2500 \mathrm{~km}$ (Fig. 6b), as with the disturbances studied by Lau and Lau (1990) and Tam and Li (2006). Thus, Fig. $6 \mathrm{~b}$ provides evidence of a substantial modification in the structure of easterly waves by the basic
TABLE 2. TD-wave characteristics for base points used in this study. Characteristics are derived from both the NCEP-NCAR 700-hPa meridional wind and OLR regression values (OLR values provided in parentheses).

\begin{tabular}{lccc}
\hline \hline Base point & $\begin{array}{c}\text { Phase speed } \\
\left(\mathrm{m} \mathrm{s}^{-1}\right)\end{array}$ & $\begin{array}{c}\text { Wavelength } \\
(\mathrm{km})\end{array}$ & $\begin{array}{c}\text { Period } \\
(\text { days })\end{array}$ \\
\hline $10^{\circ} \mathrm{N}, 95^{\circ} \mathrm{W}$ & $-11.3(-10.5)$ & $4400(3300)$ & $4.5(4.7)$ \\
$7.5^{\circ} \mathrm{N}, 172.5^{\circ} \mathrm{E}$ & $-12.0(-11.6)$ & $4200(4000)$ & $4.0(4.0)$ \\
\hline
\end{tabular}

state shown in Figs. 1b, 2 as they propagate into the far west Pacific, consistent with the overall weakening and confluence of the zonal wind over this region (e.g., Sobel and Bretherton 1999).

Figure 7 shows the results of regressing NCEPNCAR $700-\mathrm{hPa}$ winds onto a $-20 \mathrm{~W} \mathrm{~m}^{-2}$ anomaly in TD-filtered OLR at $10^{\circ} \mathrm{N}, 95^{\circ} \mathrm{W}$ for lags -4 to +4 days. The contours represent the streamfunction, while the arrows represent wind direction and speed. Arrows indicate where wind regressions are $90 \%$ significant. Also shown are regressions of OLR data onto TD-filtered OLR for the same base point (shaded). Using this far eastern base point for our regressions, we clearly see that some of the easterly wave signal in OLR and circulation is originating farther east within the Atlantic, with $90 \%$ significant wind vectors observed within the Atlantic at all lags. The gap in the mountains near Panama may be important for this Atlantic connection, as evidenced by a convective signal crossing there, but this is not seen over Central America when base points farther north are used (not shown). We note that previous observational and modeling work has suggested that easterly wave circulations would be substantially modified as they cross the orography over Central America (e.g., Zehnder et al. 1999).

The convection is located north and east of the cyclonic centers in the southerlies in this region, consistent with the buoy regressions shown in Fig. 5a, and with the observations of easterly waves over the eastern Pacific during EPIC by Petersen et al. (2003). There is also evidence of a northwestward propagation of OLR once the waves enter the east Pacific. This northwestward propagation of convection, as well as a separation from the circulation features farther south, is most evident for lags 0 and +2 (Figs. $7 \mathrm{c}, \mathrm{d}$ ). For instance, the suppressed region at about $12^{\circ} \mathrm{N}, 110^{\circ} \mathrm{W}$ at lag 0 is seen to be north and east of the circulation centers, which are located at about $5^{\circ}-7.5^{\circ} \mathrm{N}$ for this base point. A similar situation is observed at lag +2 , where the convective and suppressed centers remain along the coast of Central America and Mexico, while the cyclonicanticyclonic couplet propagates westward. Convection shifts more into the southerlies west of about $120^{\circ} \mathrm{W}$, 



FIG. 7. Regressions of OLR (filled contours) and NCEP-NCAR 700-hPa wind vectors and streamfunction (solid contours are positive; dashed contours are negative; contour interval $1 \times 10^{5} \mathrm{~s}^{-1}$ ) for the base point $10^{\circ} \mathrm{N}, 95^{\circ} \mathrm{W}$. Wind arrows indicate where wind regressions are $90 \%$ significant.

but is still not quite in quadrature with vorticity, as is seen in Atlantic easterly waves (see Kiladis et al. 2006 and references therein).

At lag 0, the circulation anomalies over Panama are very pronounced and the cyclonic-anticyclonic streamfunction centers are evident west to about the date line. The circulations start out elongated from southwest to northeast in the far eastern portion of the Pacific, be- coming more isotropic farther west. The circulation patterns also shift from being north of the equator in the eastern portion of the basin to being more along the equator farther west. This is most evident at positive lags, where the circulation anomalies to the west are strongest. The southwest to northeast tilt of the waves in the eastern Pacific seen in Fig. 7 implies a flux of easterly momentum equatorward from the easterly 

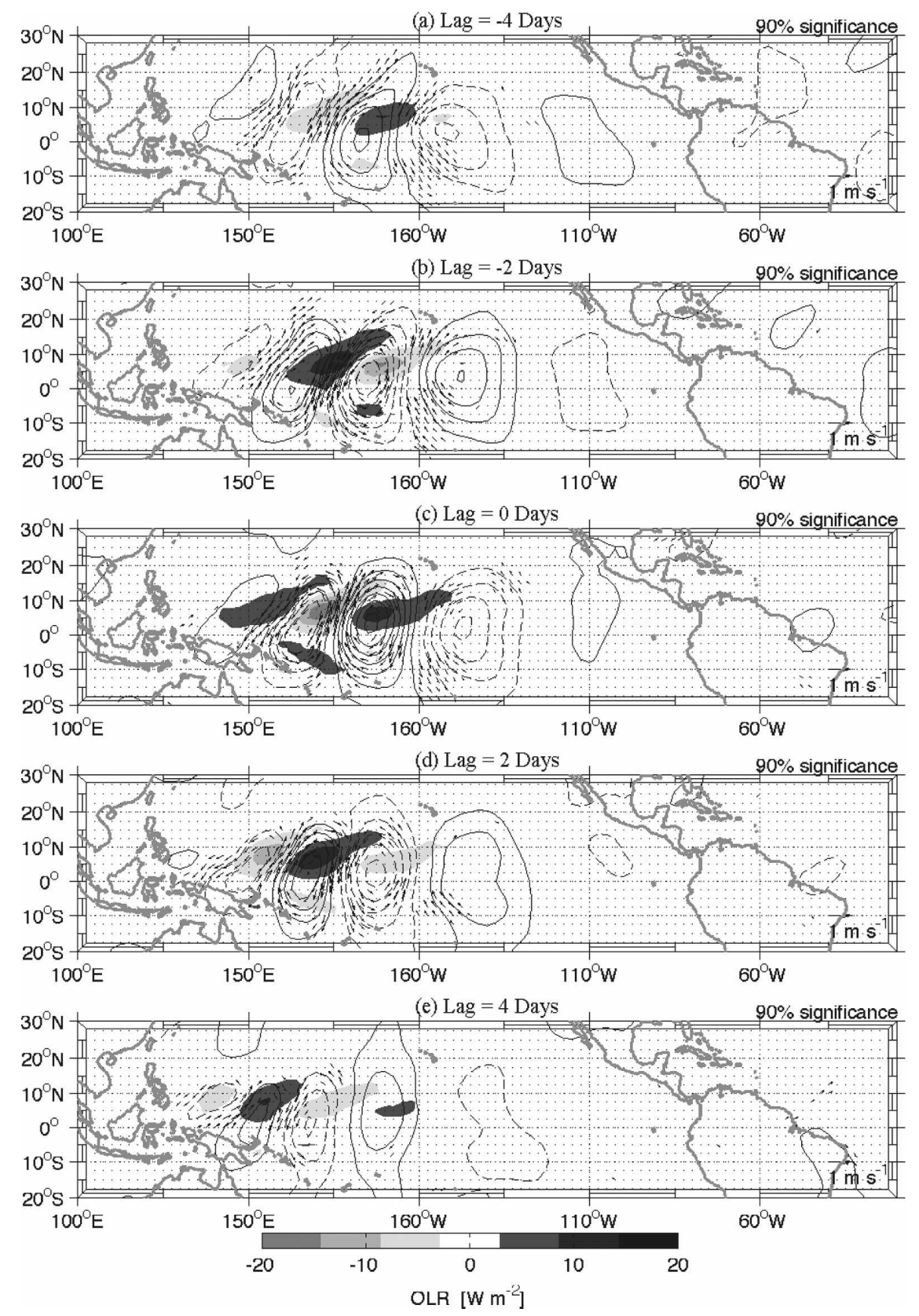

FIG. 8. Same as Fig. 7 but for base point at $7.5^{\circ} \mathrm{N}, 172.5^{\circ} \mathrm{E}$.

maximum north of the equator in Fig. 1b, and, as will be shown in section 7, is indicative of a barotropic conversion of zonal kinetic to eddy kinetic energy. As is wellknown over Africa, not all Pacific easterly waves have an associated OLR signal, as seen for instance in Fig. 7e near $160^{\circ} \mathrm{W}$.

We compare the easterly wave structure at $95^{\circ} \mathrm{W}$ with that at $172.5^{\circ} \mathrm{E}$ in Fig. 8. Comparing positive lags in Fig. 7 to negative lags in Fig. 8, we see that the wave structures along the equator in both analyses indicate that west Pacific waves do not seem to have strong precursors in the east, but amplify significantly in situ once formed over the central part of the basin. Convection moves into the trough as the waves propagate farther west (Fig. 8e), a shift also noted by Reed and Recker (1971).

As these waves propagate westward, they tend to gain a more southwest to northeast tilt, similar to the waves in the eastern Pacific. As seen in Fig. 1b, this is also a region of weak easterly shear equatorward of 
(a)

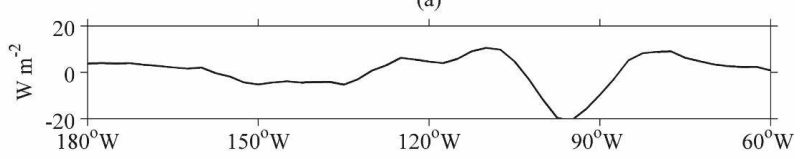

(b)

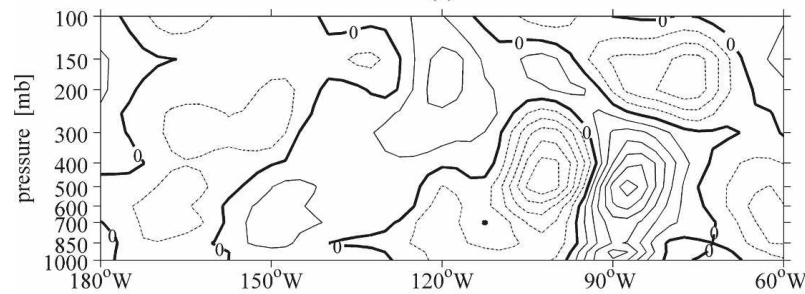

(c)

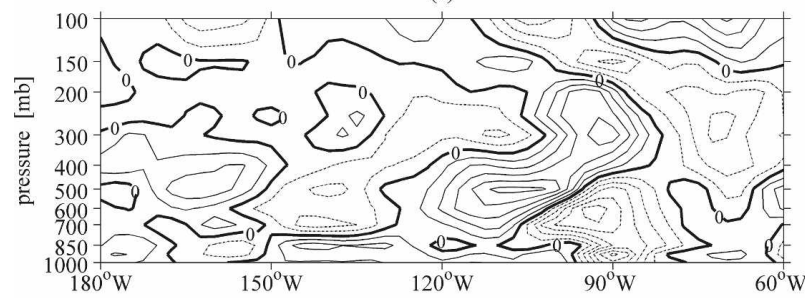

(d)

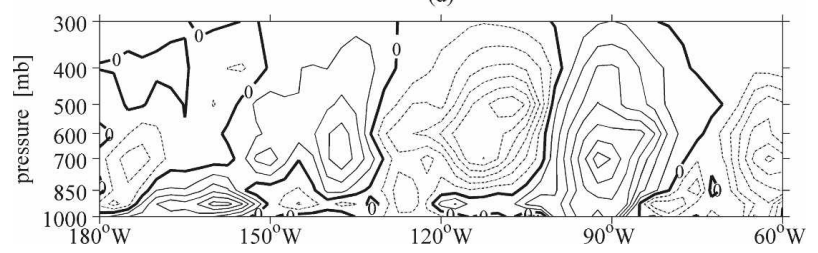

FIG. 9. Profiles of (a) TD-filtered OLR and regressions of NCEP-NCAR, (b) meridional wind, (c) air temperature, and (d) specific humidity in the zonal plane along $10^{\circ} \mathrm{N}$ for base point at $10^{\circ} \mathrm{N}, 95^{\circ} \mathrm{W}$. Positive anomalies are shown as solid contours and negative anomalies are shown as dotted contours. Contour intervals are $0.15 \mathrm{~m} \mathrm{~s}^{-1}, 0.02^{\circ} \mathrm{C}$, and $0.02 \mathrm{~g} \mathrm{~kg}^{-1}$.

about $15^{\circ} \mathrm{N}$. Thus, as in the eastern Pacific, the tilt of these waves suggests a barotropic conversion from zonal kinetic to eddy kinetic energy. However, as will be shown in section 7, energetics calculations indicate that barotropic conversions are not the primary source of energy for these waves, as easterly wave convection becomes more intense to the west (Fig. 3).

\section{Vertical eddy structure}

\section{a. Structure in reanalysis}

Figure 9 shows TD-filtered OLR and the vertical structure in the zonal plane along $10^{\circ} \mathrm{N}$ in meridional wind, temperature, and specific humidity for the base point at $10^{\circ} \mathrm{N}, 95^{\circ} \mathrm{W}$ at 0 lag. NCEP-NCAR specific humidity is only available from 1000 to $300 \mathrm{hPa}$. The meridional wind structure extends to about $300 \mathrm{hPa}$ and shows little or a slightly eastward tilt with height (Fig. $9 b$ ). A similar vertically upright structure, with a rever- sal of the meridional flow above $300 \mathrm{hPa}$, is comparable to that seen in easterly waves within the ITCZ over the African continent (Kiladis et al. 2006). The maximum meridional wind anomalies at this location are observed at about $500-600 \mathrm{hPa}$.

The temperature structure tilts eastward with height between 700 and $300 \mathrm{hPa}$, and westward above this level (Fig. 9c). Below $500 \mathrm{hPa}$, cold anomalies are observed within and behind the convection, consistent with the buoy temperature regressions in Fig. 5a, while warm anomalies are observed from 500 to $200 \mathrm{hPa}$ in this phase of the wave. This structure is also seen in the majority of other convectively coupled equatorial waves (Wheeler et al. 2000; Straub and Kiladis 2003), and in African easterly waves (Kiladis et al. 2006), although in the latter case the "elbow" of the tilt is located at the AEJ level of $700 \mathrm{hPa}$. The in-phase relationship between upper-tropospheric temperature anomalies and convection at $95^{\circ} \mathrm{W}$ (and thus diabatic heating due to latent heat release) implies a conversion from eddy available potential to eddy kinetic energy as an energy source for the waves.

Moist anomalies are observed throughout the troposphere within the region of the convection (Fig. 9d). However, near the surface up to about $750 \mathrm{hPa}$, anomalously high moisture is also observed in the warm air ahead of the convection, consistent with the buoy regressions in Fig. 5b and with Petersen et al.'s (2003) composites. The sequence indicates that moistening occurs first at the 925-hPa level and then spreads upward into the convective center. A rapid moistening of the entire lower and midtroposphere occurs within the deep convection, followed first by a cooling then drying at low levels while it is still moist aloft. This is consistent with implied progression of shallow convection ahead of the wave, which then develops into deep convection before transitioning into stratiform precipitation behind the disturbance, as seen in a variety of other convectively coupled waves (e.g., Takayabu et al. 1996; Straub and Kiladis 2003; Haertel and Kiladis 2004; Kiladis et al. 2006).

The vertical profiles for the $172.5^{\circ} \mathrm{E}$ base point in the zonal plane along $7.5^{\circ} \mathrm{N}$ are shown in Fig. 10. The meridional wind vertical structure indicates a slight eastward tilt with height; similar to what is observed for the $95^{\circ} \mathrm{W}$ base point. The convection is closer to the center of the cyclonic circulation at this location at $300 \mathrm{hPa}$, while it is within the southerlies below this level. Cold anomalies are observed at the surface within the convective center, with the coldest anomalies at $500 \mathrm{hPa}$ behind the convection. Warm anomalies are observed over a broad region between 450 and $200 \mathrm{hPa}$ within the trough, once again consistent with latent heating as 
(a)

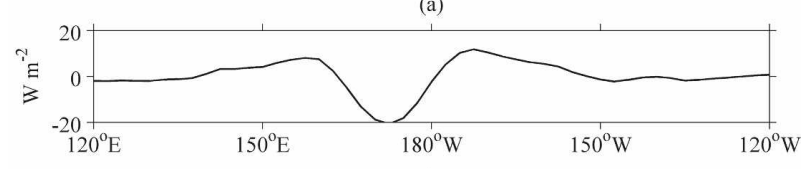

(b)

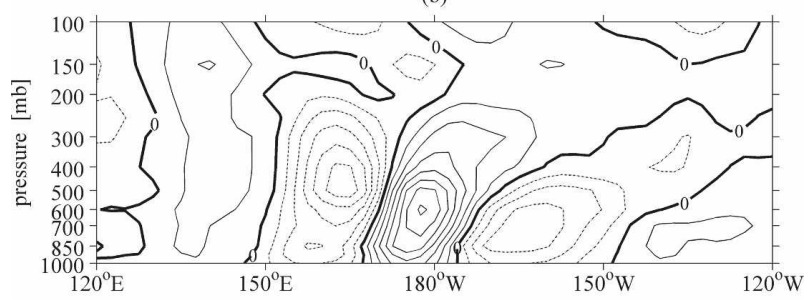

(c)

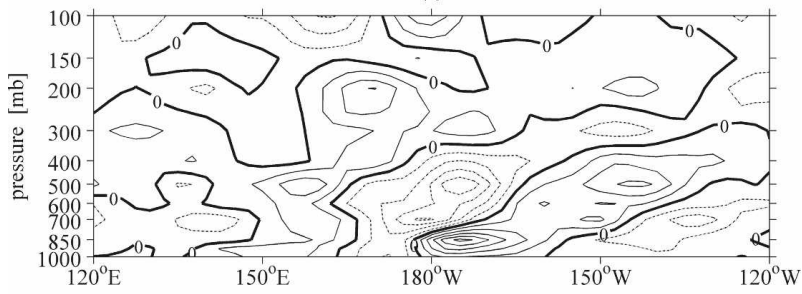

(d)

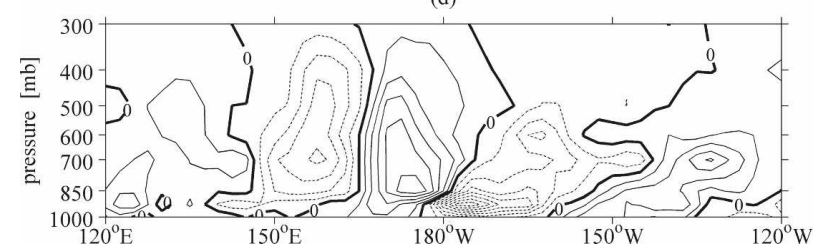

FIG. 10. Same as Fig. 9 but for base point at $7.5^{\circ} \mathrm{N}, 172.5^{\circ} \mathrm{E}$ in the zonal plane along $7.5^{\circ} \mathrm{N}$.

an energy source, as at $95^{\circ} \mathrm{W}$. The humidity anomalies at this location indicate moistening occurring ahead of the convection at low levels, followed by a deep moistening throughout the troposphere within the convection. The upper-level moisture anomalies at $172.5^{\circ} \mathrm{E}$ are not as broad as those at $95^{\circ} \mathrm{W}$ and the temperature and moisture anomalies in general are not as large as those at $95^{\circ} \mathrm{W}$. This difference may in part be due to a fundamental change in the nature of the more vigorous mean convection over the west Pacific warm pool whose eastern edge extends beyond $172.5^{\circ} \mathrm{E}$, as well as to the change in the basic state (discussed farther below).

\section{b. Structure in radiosonde data}

We compare the reanalysis vertical profiles at $7.5^{\circ} \mathrm{N}$, $172.5^{\circ} \mathrm{E}$ with those obtained from the IGRA sounding station at Majuro $\left(7.1^{\circ} \mathrm{N}, 171.4^{\circ} \mathrm{E}\right)$. We also include the vertical profiles from the IGRA sounding station at Koror $\left(7.3^{\circ} \mathrm{N}, 134.5^{\circ} \mathrm{E}\right)$ to further characterize the change in easterly wave structure indicated by the regressions in Fig. 8e. Similar results are obtained by using the nearest reanalysis gridpoint data to these stations, although the radiosonde plots show more detail due to their higher vertical resolution. Figure 11 shows TD-filtered OLR, as well as the meridional wind, temperature, and moisture profiles as a function of time at these locations. The meridional wind profile at Majuro tilts to the east with height up to about $250 \mathrm{hPa}$, with a maximum around $600 \mathrm{hPa}$, abruptly changing to tilt westward with height above this level (Fig. 11b). The structure below $300 \mathrm{hPa}$ is very similar to the regressions of NCEP-NCAR reanalyses at $7.5^{\circ} \mathrm{N}, 172.5^{\circ} \mathrm{E}$ (Fig. 10b). The displacement of the maximum wind center to lower levels in time below $250 \mathrm{hPa}$ at Majuro suggests downward energy propagation. Above this level, downward phase propagation over time implies upward energy dispersion, generated by a moving heat source, as seen in other equatorial waves (e.g., Wheeler et al. 2000).

In contrast, the lower-tropospheric tilt of meridional wind at Koror (Fig. 11f) shows downward phase propagation over time, or a slightly westward tilt with height. This change in vertical structure is in good agreement with Reed and Recker (1971), who analyzed sounding data from these same island locations for July-September 1967. These authors attributed the change in vertical tilt with longitude to changes in the background vertical shear, consistent with the modeling and theoretical result of Holton (1971). The background state between 700 and $300 \mathrm{hPa}$ shown in Fig. 2 supports these conclusions, indicating very little shear with height in the eastern portion of the basin, slight westerly shear near $170^{\circ} \mathrm{E}$, and easterly shear west of about $150^{\circ} \mathrm{E}$.

The convection is seen to shift from the center of the trough at Majuro in the central Pacific to the northerlies in the far west Pacific at Koror (Fig. 11). This shift in the convection with respect to the wave structure is also observed in the reanalyses; however, the convection is within the southerlies in the vicinity of Majuro shifting to the center of the trough near $135^{\circ} \mathrm{E}$ (Fig. 8e).

Temperature profiles for Majuro and Koror are shown in Figs. 11c,g along with moisture profiles in Figs. 11d,h. The temperature profiles at Majuro indicate a cold anomaly within and behind the trough with two maxima, one at the surface and the other near 700 $\mathrm{hPa}$, and a warm anomaly aloft at about $250-300 \mathrm{hPa}$. The pronounced surface cooling (Fig. 11c) and drying (Fig. 11d) following the minimum OLR is likely due to convective downdrafts transporting low-entropy air from midlevels into the boundary layer (Zipser 1977). The upper-level warm anomaly is in phase with the implied convection at Majuro, while the reanalyses indicate a maximum in upper-level warming slightly to the west of (ahead of) the convection for the base point at $172.5^{\circ} \mathrm{E}$ (Fig. 10c). Wheeler et al. (2000) also note a tendency for warm anomalies to lead convection for 
(a)

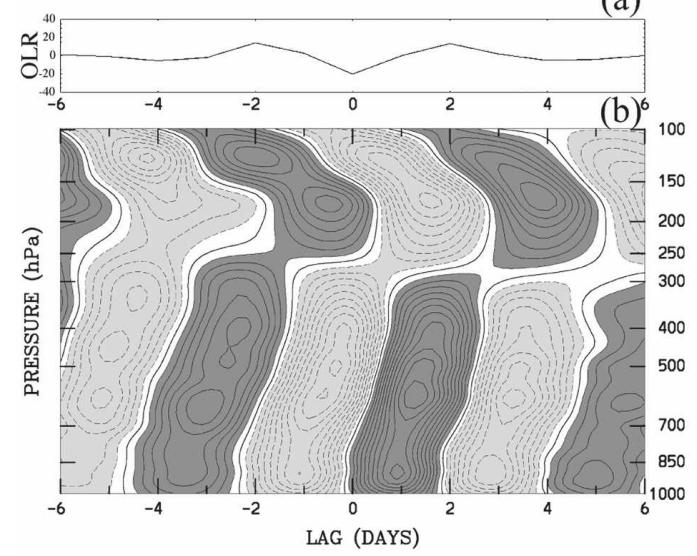

(c) 100



(d)

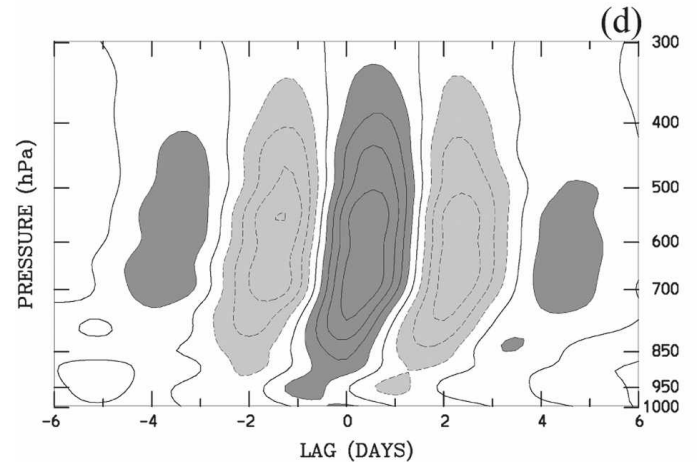

(e)
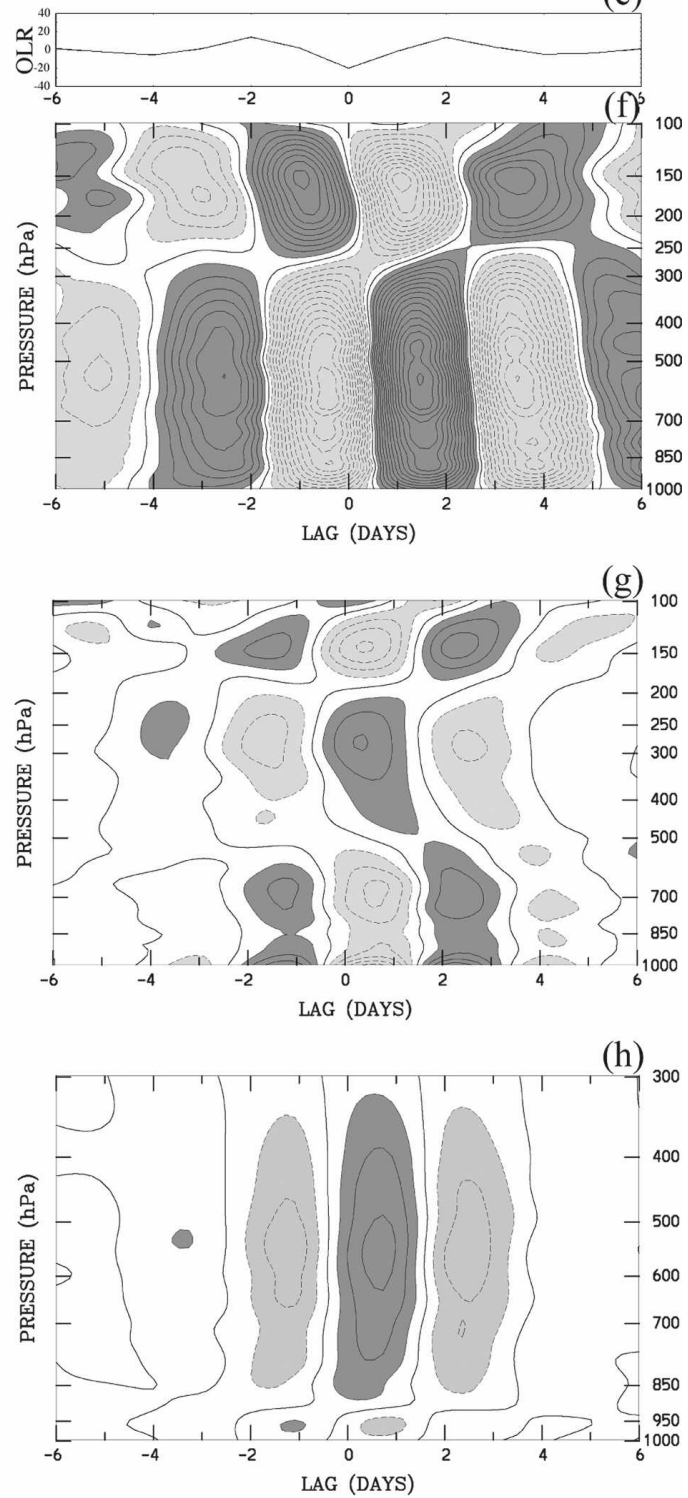

FIG. 11. (a) TD-filtered OLR and profiles of (b) meridional wind, (c) air temperature, and (d) specific humidity regressions at Majuro $\left(7.1^{\circ} \mathrm{N}, 171.4^{\circ} \mathrm{E}\right)$. (e)-(h) Same as (a)-(d), but for Koror $\left(7.3^{\circ} \mathrm{N}, 134.5^{\circ} \mathrm{E}\right)$. Positive anomalies are shown as dark shading and negative anomalies are shown as light shading. Contour intervals are $0.1 \mathrm{~m} \mathrm{~s}^{-1}$, $0.1^{\circ} \mathrm{C}$, and $0.1 \mathrm{~g} \mathrm{~kg}^{-1}$.

other equatorial waves in reanalysis, while radiosonde observations generally show the convection coincident with the warm anomalies (e.g., Straub and Kiladis 2003; Haertel and Kiladis 2004; Kiladis et al. 2006). The upper-level warm anomaly at Koror is at about $300 \mathrm{hPa}$ and slightly behind the convection. As with the meridional wind, the overall temperature structure is similar at both Koror and Majuro, except for a change toward eastward vertical tilts at Koror, presumably related to changes in the basic-state flow and its interaction with the diabatic heating within the convecting region.
The observed moisture structure for the IGRA stations indicates moist anomalies ahead of the trough and convection at low levels (up to about $850 \mathrm{hPa}$ ), followed by deep moistening aloft within and behind the trough and convective center, and drying near the surface behind the trough (Figs. 11d,h). This structure is similar to what is observed in the reanalyses for both $95^{\circ} \mathrm{W}$ and $172.5^{\circ} \mathrm{E}$. There is a less gradual transition and more of a two-tiered structure at Koror (Fig. 11h) when compared to Majuro (Fig. 11d), along with less amplitude in the moisture perturbations for a given OLR signal. This 
is perhaps related to a real difference in the nature of convection between the two locations, with the Koror warm pool region being generally more moist and thus giving a weaker signal.

\section{Energetics}

In previous sections we noted evidence of a conversion from mean flow to eddy kinetic energy within Pacific easterly waves based on the tilt of the wave structure with respect to profiles of mean wind shear. In addition, we noted the implied conversion of eddy potential energy to eddy kinetic energy based on the vertical profiles of temperature anomalies with respect to the location of upward motion within the convective signal. In this section we estimate the conversion terms in the energy budget using reanalyses to better understand the forcing of easterly waves in the Pacific.

Our approach consists of a statistical representation of easterly waves superimposed on a $25-\mathrm{yr}$ June-November mean flow. Thus, any variable $a$ in our system is written as $a=a_{\text {clim }}+a^{\prime}$, where $a_{\text {clim }}$ is the June-November climatology at a particular location and $a^{\prime}$ is the TD-wave perturbation at that location obtained from the regressions. In this case $\overline{a^{\prime}}=0$, where the overbar denotes an average over one or more wave periods. To account for stratification, we further divide $\theta_{\text {clim }}$ into a regional mean $(\langle\rangle)$ and deviation from the regional mean $(\Delta): \theta_{\text {clim }}(x, y, p)=\left\langle\theta_{\text {clim }}\right\rangle(p)+\Delta \theta_{\text {clim }}(x, y, p)$. This approach differs from previous studies of easterly wave energetics for which the calculations are based on a case study rather than a wave climatology (e.g., Norquist et al. 1977; Reed et al. 1988). In addition we define wave perturbations with respect to temporal rather than longitudinal averages, as was done, for example, by Reed et al. (1988). This gives a more accurate estimate over wave cycles than an average over longitude, where arbitrary domain boundaries would have to be drawn.

A derivation of time-mean eddy energetics can be found in Cronin and Watts (1996) but for ocean eddies. Detailed derivations of eddy energetics for the atmosphere using longitudinal averaging can be found in, for example, Lorenz (1955), Norquist et al. (1977), and Plumb (1983). Using these references as a guide, we define the mean eddy kinetic $\left(K_{E}\right)$ and potential energy $\left(A_{E}\right)$ as

$$
\begin{aligned}
& K_{E}=(1 / 2)\left({\overline{u^{\prime 2}}}^{t}+{\overline{v^{2}}}^{t}\right) \\
& A_{E}=\frac{R}{p} \frac{1 / 2{\overline{T^{\prime 2}}}^{t}}{\partial\left\langle\theta_{\text {clim }}\right\rangle / \partial p},
\end{aligned}
$$

where $R$ is the universal gas constant for dry air and the angle bracket denotes a horizontal average. Averaging over the wave period, the eddy energy budgets can then be written as

$$
\frac{\partial \overline{K_{E}} t}{\partial t}=-\mathrm{ADV}_{\mathrm{KE}}+C_{\mathrm{AE} \rightarrow \mathrm{KE}}+C_{\mathrm{KM} \rightarrow \mathrm{KE}}+F_{\mathrm{KE}}-D=0
$$

$$
\frac{\partial \overline{A_{E}} t}{\partial t}=-\mathrm{ADV}_{\mathrm{AE}}+C_{\mathrm{AM} \rightarrow \mathrm{AE}}-C_{\mathrm{AE} \rightarrow \mathrm{KE}}+F_{\mathrm{AE}}+S=0,
$$

where $C_{\mathrm{AE} \rightarrow \mathrm{KE}}$ is the conversion from eddy available potential energy to eddy kinetic energy, $C_{\mathrm{KM} \rightarrow \mathrm{KE}}$ is the conversion from mean to eddy kinetic energy, and $C_{\mathrm{AM} \rightarrow \mathrm{AE}}$ is the conversion from mean available potential energy to eddy potential energy. Additional terms not found in the longitudinal averaging approach are the advection by the mean flow terms, $A_{\mathrm{CDE}}$ and $\mathrm{ADV}_{\mathrm{AE}}$. Other additional terms are the fluxes of eddy kinetic $\left(F_{\mathrm{KE}}\right)$ and eddy available potential energy $\left(F_{\mathrm{AE}}\right)$ at the boundaries of a defined region, as well as the dissipation of eddy kinetic energy $(D)$ and sources and sinks of eddy available potential energy due to heating (S). As in Norquist et al. (1977), we make no attempt to calculate these additional terms primarily because the reanalysis data and regression technique used to define the waveform in this study do not permit reliable estimates of them.

The conversion terms from the above equations are

$$
\begin{aligned}
C_{\mathrm{AE} \rightarrow \mathrm{KE}} & =\frac{R}{p} \overline{\omega^{\prime} T^{\prime}}, \\
C_{\mathrm{KM} \rightarrow \mathrm{KE}} & =\overline{u^{\prime} \mathbf{u}^{\prime}} \cdot \nabla u_{\mathrm{clim}}+\overline{v \mathbf{u}^{\prime}} \cdot \nabla v_{\mathrm{clim}} \\
C_{\mathrm{AM} \rightarrow \mathrm{AE}} & =-\frac{R}{p} \frac{\overline{\mathbf{u}^{\prime} T^{\prime}} \cdot \nabla \Delta \theta_{\mathrm{clim}}}{\partial\left\langle\theta_{\mathrm{clim}}\right\rangle / \partial p},
\end{aligned}
$$

where $c_{p}$ is the specific heat at constant pressure, $\omega=$ $d p / d t$, and $\nabla$ is the three-dimensional divergence operator. For these calculations, the overbar indicates an average over \pm 4 -day lag and the angle brackets indicate an area average taken over $\pm 20^{\circ}$ from the base point in longitude and from $5^{\circ} \mathrm{S}$ to $15^{\circ} \mathrm{N}$ in latitude.

The most prominent terms from the above equations are presented in a vertically integrated form and as a meridional profile in Figs. 12a,b and 13a,b, respectively. The meridional profiles of $C_{\mathrm{AE} \rightarrow \mathrm{KE}}$ as well as eddy temperature anomalies at lag 0 are shown for the $95^{\circ} \mathrm{W}$ (Fig. 12a) and $172.5^{\circ} \mathrm{E}$ (Fig. 12b) base points (note that these two panels have a different scaling than Figs. $12 \mathrm{c}, \mathrm{d}$ and 13). When compared to the other terms in Figs. 12 and 13, $C_{\mathrm{AE} \rightarrow \mathrm{KE}}$ is the dominant term shown for the waves at both locations especially at upper levels, and represents a baroclinic conversion due to ver- 
(a)
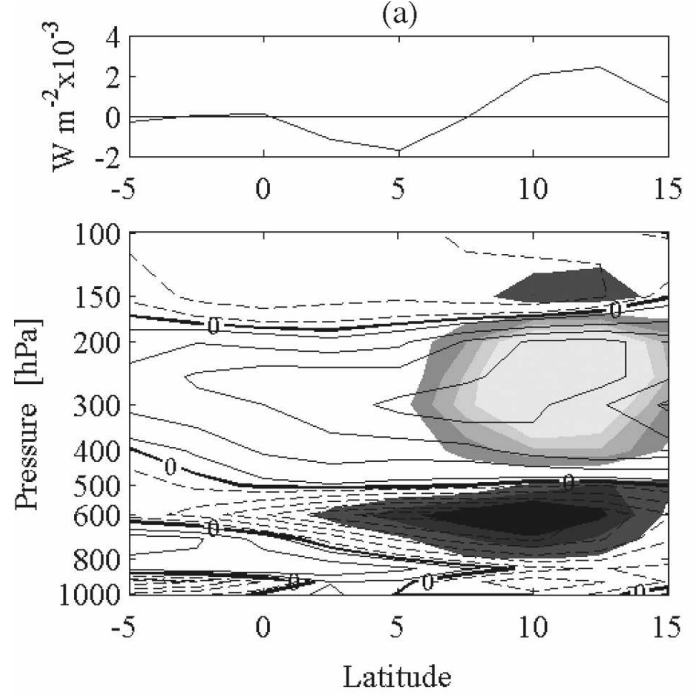

(b)
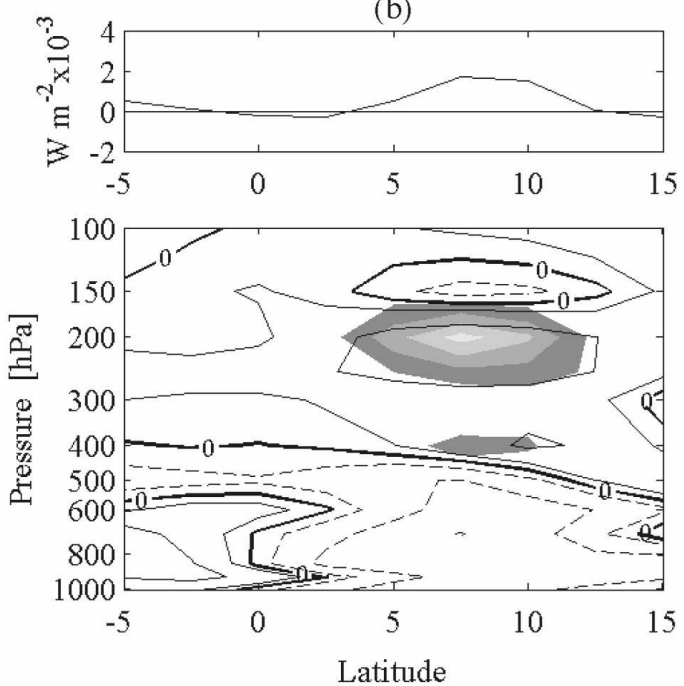

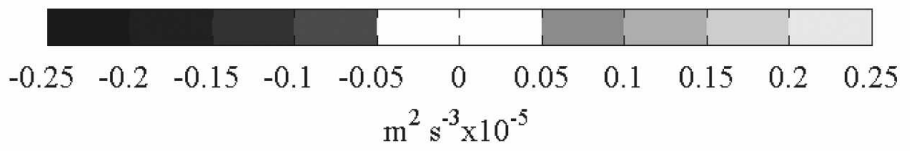

(c)
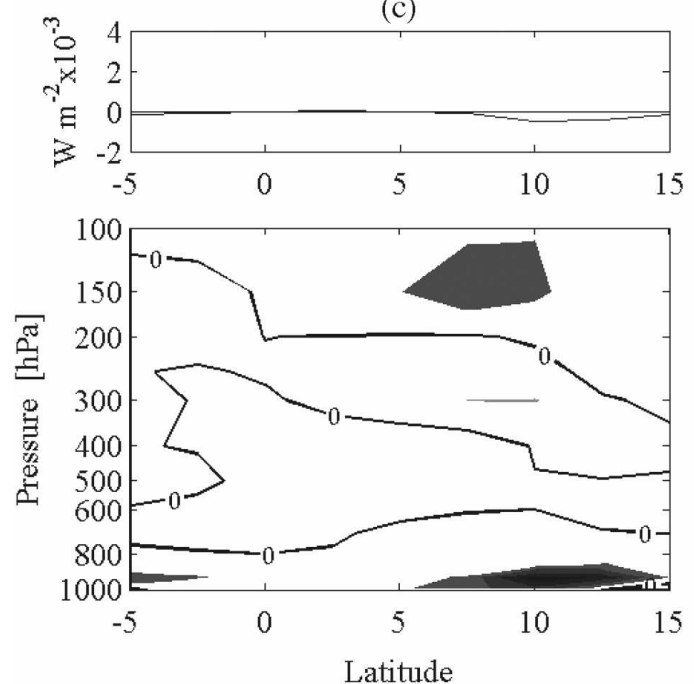

(d)
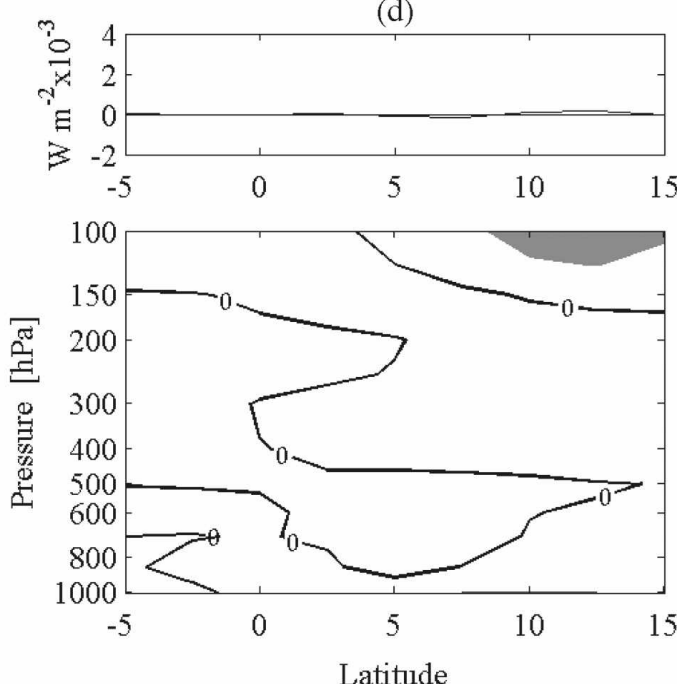

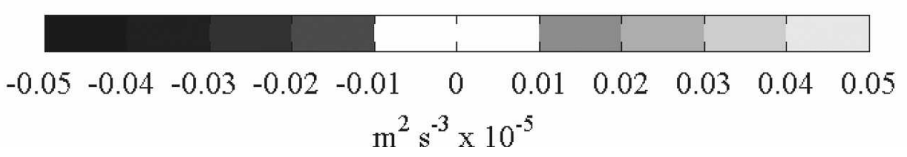

FIG. 12. Meridional sections of $T^{\prime}$ (contours) and $g \times C_{\mathrm{AE} \rightarrow \mathrm{KE}}$ (shading) for (a) $10^{\circ} \mathrm{N}, 95^{\circ} \mathrm{W}$ and (b) $7.5^{\circ} \mathrm{N}$, $172.5^{\circ} \mathrm{E}$ base points. (c), (d) Same as (a), (b), but for $\partial \theta_{\text {clim }} / \partial y$ (contours) and $g R / p\left(\partial\left\langle\theta_{\text {clim }}\right\rangle / \partial p\right)^{-1} \overline{v^{\prime} T^{\prime} t} \partial d \theta_{\text {clim }} / \partial y$ (shading) (the mean meridional convection term from $C_{\mathrm{AM} \rightarrow \mathrm{AE}}$ scaled by gravity). Contour intervals are $0.02^{\circ} \mathrm{C}$ starting at $0.01^{\circ} \mathrm{C}$ in (a), (b) and $0.05^{\circ} \mathrm{C} \mathrm{km}^{-1}$ in (c), (d). Negative contours are dashed; positive contours are solid. Vertically integrated form is shown above each profile. See text for description of terms.

tical overturning of rising warm air and sinking cold air. Although calculation of the diabatic heating term using reanalysis is problematic, warm temperature anomalies at lag 0 do coincide with upward motion in the analysis (not shown) and also where OLR is a minimum at both locations, suggesting that latent heating from the convection coupled to the waves generates eddy available potential energy. This result supports the conclusions inferred qualitatively in previous studies (e.g., Tai and Ogura 1987; Takayabu and Nitta 1993; Lau and Lau 
(a)
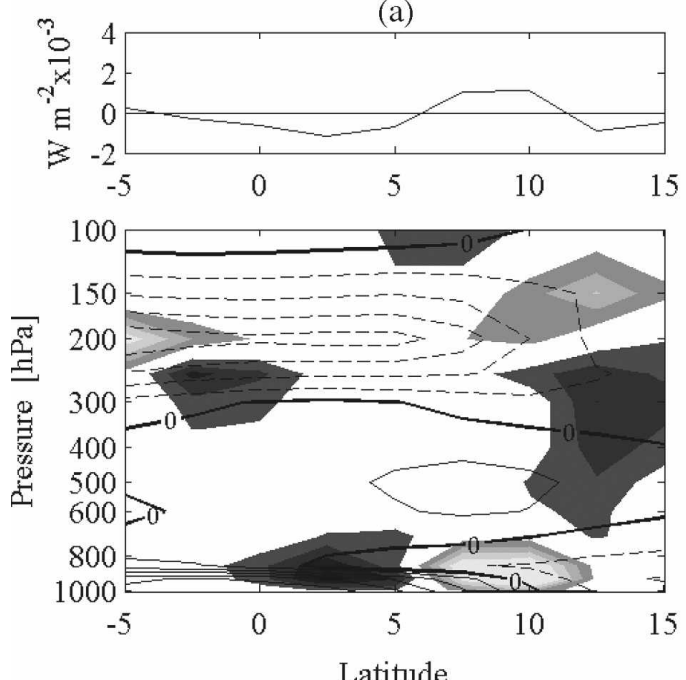

Latitude
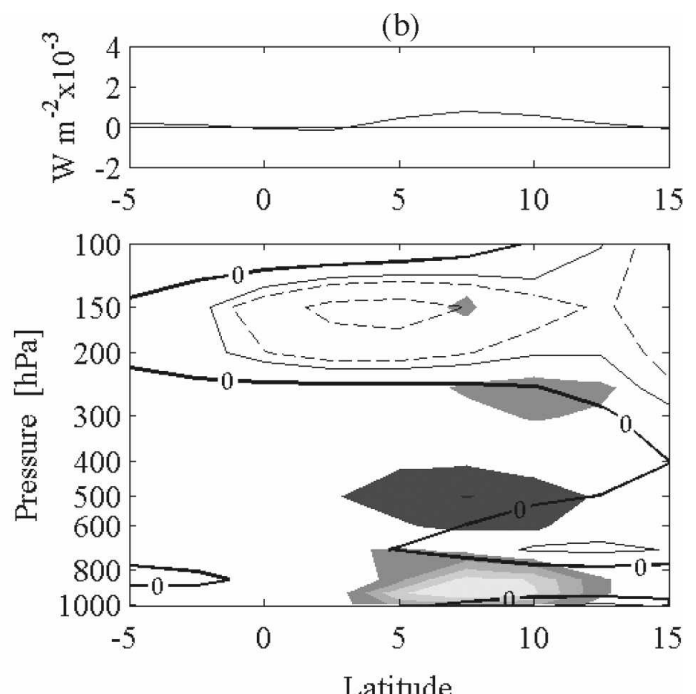

Latitude

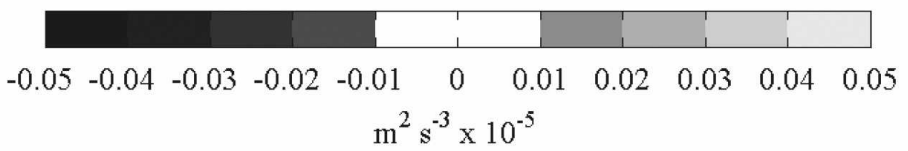

(c)
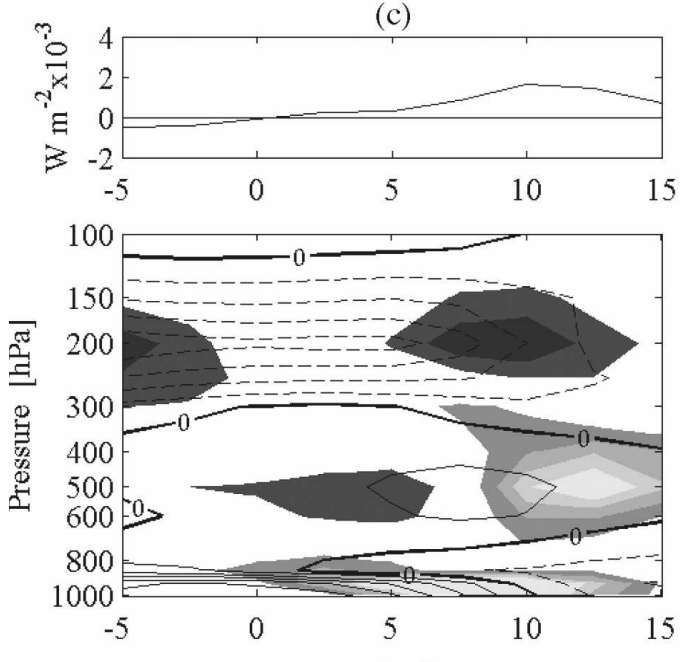

Latitude (d)
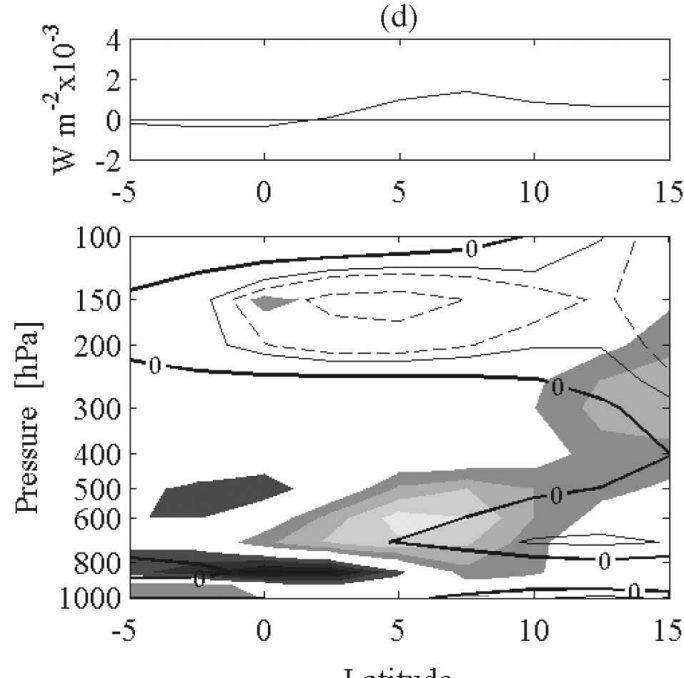

Latitude

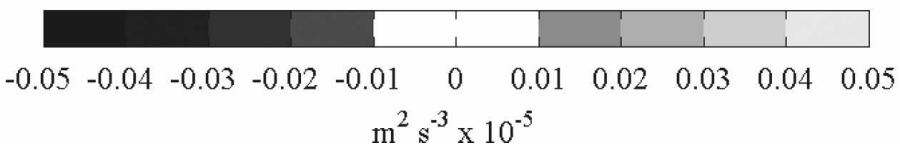

FIG. 13. Meridional sections of $u_{\text {clim }}$ (contours) and the $\overline{u^{\prime} v^{\prime}} \partial u_{\text {clim }} / \partial y$ term (shading) from $C_{\mathrm{KM} \rightarrow \mathrm{KE}}$ for (a) $10^{\circ} \mathrm{N}$, $95^{\circ} \mathrm{W}$ and (b) $7.5^{\circ} \mathrm{N}, 172.5^{\circ} \mathrm{E}$ base points. (c), (d) Same as (a), (b), but for $v_{\text {clim }}$ and the $\overline{v^{\prime 2}} \partial v_{\text {clim }} / \partial y$ term from $C_{\mathrm{KU} \rightarrow \mathrm{KE}}$. Both terms are scaled by gravity. Contour intervals are $2 \mathrm{~m} \mathrm{~s}^{-1}$ in (a), (b) and $1 \mathrm{~m} \mathrm{~s}^{-1}$ in (c), (d). Negative contours are dashed; positive contours are solid. Vertically integrated form is shown above each profile. See text for description of terms.

1992) that latent heating is a crucial energy source for the maintenance of Pacific easterly waves.

In Figs. 12c,d we show the second term in (5) for $C_{\mathrm{AM} \rightarrow \mathrm{AE}}$, along with the meridional gradients in JuneNovember climatologies of potential temperature for the $95^{\circ} \mathrm{W}$ and $172.5^{\circ} \mathrm{E}$ base points, respectively. It is perhaps not surprising that this term is small since unlike with the African waves adjacent to the Sahara, there is no strong heat flux into the Pacific ITCZ from the surrounding regions.

Norquist et al. (1977) found that $C_{\mathrm{KM} \rightarrow \mathrm{KE}}$ was a significant energy source for Atlantic waves, and, in par- 
ticular, that it was the conversion from the meridional shear in the zonal mean wind to eddy kinetic energy that was most important. We have plotted this term in Figs. $13 \mathrm{a}, \mathrm{b}$ for the $95^{\circ} \mathrm{W}$ and $172.5^{\circ} \mathrm{E}$ base points, respectively, along with the June-November zonal wind climatologies at these locations. This term is generally smaller than $C_{\mathrm{AE} \rightarrow \mathrm{KE}}$ except near $850 \mathrm{hPa}$ at the latitudes of the ITCZ, where some conversion from mean zonal flow to eddy energy is observed. The conversion from the meridional shear in the meridional mean wind to eddy energy is plotted in Figs. 13c,d along with the June-November meridional wind climatologies. A conversion of energy from the mean meridional wind to the eddy is seen at $600-700 \mathrm{hPa}$ near the latitudes of the ITCZ at both locations, suggesting that lateral shear in the mean meridional wind may be of greater importance to the Pacific waves than lateral shear in the zonal wind found for the African waves, although a detailed comparison of budgets between the regions using a consistent methodology would be necessary to confirm this.

\section{Summary and conclusions}

This study presents a statistical analysis of easterly wave structure across the Pacific basin using in situ data and reanalyses. Easterly wave variability is isolated from observed OLR using a spectral filter in the "TD band" following the technique of Wheeler and Kiladis (1999). The wave structure is then determined by regressing wind, temperature, and specific humidity onto the filtered OLR. This method isolates the dynamic and thermodynamic structure of the surface data, soundings, and reanalyses best correlated with the observed easterly wave convective signal.

In the far eastern portion of the basin the meridional wind structure of the waves shows little tilt with height, with the maximum anomalies observed near 500-700 $\mathrm{hPa}$. The convection is observed slightly behind the lower-tropospheric trough in these waves. The wave speed estimated from the reanalyses at $700 \mathrm{hPa}$ is -11.3 $\mathrm{m} \mathrm{s}^{-1}$, while near the surface the TAO buoys indicate wave speeds closer to $-13.6 \mathrm{~m} \mathrm{~s}^{-1}$. The OLR data suggest that the convective envelope moves at -10.5 $\mathrm{m} \mathrm{s}^{-1}$, slower than either of the wave speed estimates. Wavelengths in this region are estimated at 4400 and $5900 \mathrm{~km}$ for the 700-hPa reanalyses and buoys, respectively, while the wavelength of the convective structure is closer to $3300 \mathrm{~km}$. A warm, moist boundary layer precedes the wave trough, followed by enhanced latent heat fluxes within the trough, and finally a convective maximum slightly behind the trough. The convective maximum is coincident with a deep tropospheric moistening, warming at upper levels, and cooling at lower levels.
The wave structure at $172.5^{\circ} \mathrm{E}$ is similar to that at $95^{\circ} \mathrm{W}$, with the waves tilting slightly to the east with height, a maximum wave signature near $600 \mathrm{hPa}$, and the convection slightly behind the wave trough at low levels. A warm, moist boundary layer is also observed ahead of the trough at this location, followed by deep moistening and cooling at low levels within and behind the convection. The speed of the convective structure is estimated at $-12.0 \mathrm{~m} \mathrm{~s}^{-1}$, closer to both the speed of the kinematic structure at $700 \mathrm{hPa}$, which remains the same at $-11.3 \mathrm{~m} \mathrm{~s}^{-1}$, and the speed of the wave near the surface estimated at $-12.2 \mathrm{~m} \mathrm{~s}^{-1}$. Consistent with these estimates, convection is observed to pass from being within the southerlies near our base point at $172.5^{\circ} \mathrm{E}$ to being within the trough near $135^{\circ} \mathrm{E}$ (Fig. 8). A shift of the convective center between the central and west Pacific seen in the reanalyses is also observed in the radiosonde data as well as in the analyses of Reed and Recker (1971).

Overall, our results suggest that Pacific easterly waves are maintained through tight coupling between convection and the circulation, a conclusion also inferred by Takayabu and Nitta (1993). By tight coupling we mean that cold anomalies at the surface and warm anomalies aloft are coincident with the convective centers, implying the source for the temperature anomalies is latent heating. The surface data suggest that evaporative flux anomalies are an order of magnitude smaller than the precipitation anomalies, suggesting that moisture convergence is important to the maintenance of the convection coupled to the waves. Unlike over West Africa, the mean zonal flow across the Pacific has no strong barotropically unstable zone where the easterly waves are obviously being formed, as noted by Tai and Ogura (1987). While there are regions across the tropical Pacific where barotropic conversion of zonal kinetic to eddy kinetic energy is indicated, our energetic analysis suggests that these terms are much smaller than those observed in the east Atlantic and over West Africa. The observed baroclinic conversions implied by the vertical tilt of the waves within the mean vertical shear are even smaller than the barotropic conversions, consistent with other studies of easterly waves over the ocean both in the Atlantic and Pacific (Thompson et al. 1979; Thorncroft and Hoskins 1994a,b; Hall et al. 2006).

Finally, our analyses indicate that the origin of some eastern Pacific waves is the Atlantic and that many also form off the coast. Some of the central Pacific waves appear to originate in situ and do not necessarily propagate all the way from the east Pacific. Several theories exist for possible sources of easterly waves in the eastern Pacific, including flow over the Mexican highlands (e.g., Zehnder 1991), and barotropic instability (Fer- 
reira and Schubert 1997; Molinari et al. 1997, 2000; Maloney and Hartmann 2000). Holland (1995) and Sobel and Bretherton (1999) suggest wave accumulation (Webster and Chang 1988) as possible amplifiers of easterly waves in the western Pacific. Our work suggests that at least on seasonal time scales, the conversion from mean flow to eddy kinetic energy is not a leading term in the energetics of easterly waves in this region. Our future work will investigate defining the mean flow over shorter intraseasonal time scales, as suggested by the work of Maloney and Hartmann (2000).

A better understanding of the origin and maintenance of easterly waves is important for improving our ability to model the tropical climate. Hodges et al. (2003) show that model representation of both midlatitude and tropical storm tracks (easterly waves) varies considerably. As these regions are important aspects of the global water and energy cycle, accurate modeling of their duration, location, and intensity is necessary for modeling both our current climate as well as any future climate change.

Acknowledgments. We thank Paul Roundy, Eric Maloney, Justin Small, and Simon de Szoeke for many interesting discussions over the course of this project. Finally, we thank two anonymous reviewers whose comments challenged us to deepen our analysis much to the benefit of the final manuscript. YLS was supported by NOAA's Office of Global Programs under Grant GC03-095. GNK was supported by NOAA's Office of Global Programs under Grant GC05-156.

\section{REFERENCES}

Burpee, R. W., 1972: The origin and structure of easterly waves in the lower troposphere of North Africa. J. Atmos. Sci., 29, 77-90.

Chang, C.-P., 1970: Westward propagating cloud patterns in the tropical Pacific as seen from time-composite satellite photographs. J. Atmos. Sci., 27, 133-138.

Cronin, M. F., and D. R. Watts, 1996: Eddy-mean flow interaction in the Gulf Stream at $68^{\circ} \mathrm{W}$. Part I: Eddy energetics. J. Phys. Oceanogr., 26, 2107-2131.

—, N. Bond, C. Fairall, J. Hare, M. J. McPhaden, and R. A. Weller, 2002: Enhanced oceanic and atmospheric monitoring underway in Eastern Pacific. Eos, Trans. Amer. Geophys. Union, 83, 205.

,$- \ldots$, C. W. Fairall, and R. A. Weller, 2006a: Surface cloud forcing in the East Pacific stratus deck/cold tongue/ITCZ complex. J. Climate, 19, 392-409.

—, C. W. Fairall, and M. J. McPhaden, 2006b: An assessment of buoy-derived and numerical weather prediction surface heat fluxes in the tropical Pacific. J. Geophys. Res., 111, C06038, doi:10.1029/2005JC003324.

Deser, C., and C. A. Smith, 1998: Diurnal and semidiurnal variations of the surface wind field over the tropical Pacific Ocean. J. Climate, 11, 1730-1748.
Dickinson, M., and J. Molinari, 2002: Mixed Rossby-gravity waves and western Pacific tropical cyclogenesis. Part I: Synoptic evolution. J. Atmos. Sci., 59, 2183-2196.

Diedhiou, A., S. Janicot, A. Viltard, and P. de Félice, 2001: Composite patterns of easterly disturbances over West Africa and the tropical Atlantic: A climatology from the 1979-95 NCEP/ NCAR reanalyses. Climate Dyn., 18, 241-253.

,,--- , and -2002 : Energetics of easterly wave disturbances over West Africa and the tropical Atlantic: A climatology from the 1979-95 NCEP/NCAR reanalyses. Climate Dyn., 18, 487-500.

Dunkerton, T. J., and M. P. Baldwin, 1995: Observation of 3-6day meridional wind oscillations over the tropical Pacific, 1973-1992: Horizontal structure and propagation. J. Atmos. Sci., 52, 1585-1601.

— , and F. X. Crum, 1995: Eastward propagating 2- to 15-day equatorial convection and its relation to the tropical intraseasonal oscillation. J. Geophys. Res., 100, 25 781-25 790.

Ferreira, R. N., and W. H. Schubert, 1997: Barotropic aspects of ITCZ breakdown. J. Atmos. Sci., 54, 261-285.

Gu, G., and C. Zhang, 2002: Westward-propagating synoptic-scale disturbances and the ITCZ. J. Atmos. Sci., 59, 1062-1075.

Haertel, P. T., and G. N. Kiladis, 2004: Dynamics of 2-day equatorial waves. J. Atmos. Sci., 61, 2707-2721.

Hall, N. M. J., G. N. Kiladis, and C. D. Thorncroft, 2006: Threedimensional structure and dynamics of African easterly waves. Part II: Dynamical modes. J. Atmos. Sci., 63, 22312245.

Hayashi, Y., 1970: A theory of large-scale equatorial waves generated by condensation heat and accelerating the zonal wind. J. Meteor. Soc. Japan, 48, 140-160.

Hodges, K. I., B. J. Hoskins, J. Boyle, and C. Thorncroft, 2003: A comparison of recent reanalysis datasets using objective feature tracking: Storm tracks and tropical easterly waves. Mon. Wea. Rev., 131, 2012-2037.

Holland, G. J., 1995: Scale interaction in the western Pacific monsoon. Meteor. Atmos. Phys., 56, 57-79.

Holton, J. R., 1971: A diagnostic model for equatorial wave disturbances: The role of vertical shear of the mean zonal wind. J. Atmos. Sci., 28, 55-64.

Hsieh, J.-S., and K. H. Cook, 2005: Generation of African easterly wave disturbances: Relationship to the African easterly jet. Mon. Wea. Rev., 133, 1311-1327.

_ and - 2007: A study of the energetics of African easterly waves using a regional climate model. J. Atmos. Sci., 64, 421440.

Jiang, C., M. F. Cronin, K. A. Kelly, and L. Thompson, 2005: Evaluation of a hybrid satellite- and NWP-based turbulent heat flux product using Tropical Atmosphere-Ocean (TAO) buoys. J. Geophys. Res., 110, C09007, doi:10.1029/ 2004JC002824.

Kiladis, G. N., and M. Wheeler, 1995: Horizontal and vertical structure of observed tropospheric equatorial Rossby waves. J. Geophys. Res., 100, 22 981-22 998.

_, C. D. Thorncroft, and N. M. J. Hall, 2006: Three-dimensional structure and dynamics of African easterly waves. Part I: Observations. J. Atmos. Sci., 63, 2212-2230.

Lau, K.-H., and N.-C. Lau, 1990: Observed structure and propagation characteristics of tropical summertime synoptic scale disturbances. Mon. Wea. Rev., 118, 1888-1913.

_ , and - 1992: The energetics and propagation dynamics of tropical summertime synoptic-scale disturbances. Mon. Wea. Rev., 120, 2523-2539. 
Liebmann, B., and H. H. Hendon, 1990: Synoptic-scale disturbances near the equator. J. Atmos. Sci., 47, 1463-1479.

Lorenz, E. N., 1955: Available potential energy and the maintenance of the general circulation. Tellus, 7, 157-167.

Madden, R. A., and P. R. Julian, 1994: Observations of the 4050-day tropical oscillation-A review. Mon. Wea. Rev., 122, 814-837.

Maloney, E. D., and D. L. Hartmann, 2000: Modulation of eastern North Pacific hurricanes by the Madden-Julian oscillation. $J$. Climate, 13, 1451-1460.

_ and _ 2001: The Madden-Julian oscillation, barotropic dynamics, and North Pacific tropical cyclone formation. Part I: Observations. J. Atmos. Sci., 58, 2545-2558.

McPhaden, M. J., and Coauthors, 1998: The Tropical OceanGlobal Atmosphere observing system: A decade of progress. J. Geophys. Res., 103, 14 169-14 240.

Mitchell, T. P., and J. M. Wallace, 1992: The annual cycle in equatorial convection and sea surface temperature. J. Climate, $\mathbf{5}$, 1140-1156.

Molinari, J., and D. Vollaro, 2000: Planetary- and synoptic-scale influences on eastern Pacific tropical cyclogenesis. Mon. Wea. Rev., 128, 3296-3307.

— D. Knight, M. Dickinson, D. Vollaro, and S. Skubis, 1997: Potential vorticity, easterly waves, and eastern Pacific tropical cyclogenesis. Mon. Wea. Rev., 125, 2699-2708.

_ D. Vollaro, S. Skubis, and M. Dickinson, 2000: Origins and mechanisms of eastern Pacific tropical cyclogenesis: A case study. Mon. Wea. Rev., 128, 125-139.

Mounier, F., G. N. Kiladis, and S. Janicot, 2007: Analysis of the dominant mode of convectively coupled Kelvin waves in the West African monsoon. J. Climate, 20, 1487-1503.

Nitta, T., Y. Nakagomi, A. Kadokura, Y. Suzuki, and N. Hasegawa, 1985: Global analysis of the lower tropospheric disturbances in the tropics during the northern summer of the FGGE year. Part I: Global features of the disturbances. $J$. Meteor. Soc. Japan, 63, 1-19.

Norquist, D. C., E. E. Recker, and R. J. Reed, 1977: The energetics of African wave disturbances as observed during Phase III of GATE. Mon. Wea. Rev., 105, 334-342.

Petersen, W. A., R. Cifelli, D. J. Boccippio, S. A. Rutledge, and C. Fairall, 2003: Convection and easterly wave structures observed in the eastern Pacific warm pool during EPIC-2001. $J$. Atmos. Sci., 60, 1754-1773.

Plumb, R. A., 1983: A new look at the energy cycle. J. Atmos. Sci., 40, 1669-1688.

Reed, R. J., and E. E. Recker, 1971: Structure and properties of synoptic-scale wave disturbances in the equatorial western Pacific. J. Atmos. Sci., 28, 1117-1133.

— D. C. Norquist, and E. E. Recker, 1977: The structure and properties of African wave disturbances as observed during Phase III of GATE. Mon. Wea. Rev., 105, 317-333.

— , E. Klinker, and A. Hollingsworth, 1988: The structure and characteristics of African easterly wave disturbances as determined from the ECMWF operational analysis/forecast system. Meteor. Atmos. Phys., 38, 22-33.

Roundy, P. E., and W. M. Frank, 2004: A climatology of waves in the equatorial region. J. Atmos. Sci., 61, 2105-2132.

Serra, Y. L., and R. A. Houze Jr., 2002: Observations of variability on synoptic timescales in the east Pacific ITCZ. J. Atmos. Sci., 59, 1723-1743.

—, M. F. Cronin, and G. N. Kiladis, 2007: Sub-seasonal variance of surface meteorological parameters in buoy observations and reanalyses. Geophys. Res. Lett., 34, L12708, doi:10.1029/ 2007 GL029506.

Sobel, A. H., and C. S. Bretherton, 1999: Development of synoptic-scale disturbances over the summertime tropical northwest Pacific. J. Atmos. Sci., 56, 3106-3127.

Straub, K. H., and G. N. Kiladis, 2002: Observations of a convectively coupled Kelvin wave in the eastern Pacific ITCZ. $J$. Atmos. Sci., 59, 30-53.

- and — , 2003: Interactions between the boreal summer intraseasonal oscillation and higher-frequency tropical wave activity. Mon. Wea. Rev., 131, 945-960.

Tai, K.-S., and Y. Ogura, 1987: An observational study of easterly waves over the eastern Pacific in the northern summer using FGGE data. J. Atmos. Sci., 44, 339-361.

Takayabu, Y. N., and M. Murakami, 1991: The structure of super cloud clusters observed in 1-20 June 1986 and their relationship to easterly waves. J. Meteor. Soc. Japan, 69, 105-125.

, and T. Nitta, 1993: 3-5 day-period disturbances coupled with convection over the tropical Pacific Ocean. J. Meteor. Soc. Japan, 71, 221-246.

, K.-M. Lau, and C.-H. Sui, 1996: Observation of a quasi-2day wave during TOGA COARE. Mon. Wea. Rev., 124, 1892-1913.

Tam, C.-Y., and T. Li, 2006: The origin and dispersion characteristics of the observed tropical summertime synoptic-scale waves over the western Pacific. Mon. Wea. Rev., 134, 16301646.

Thompson, R. M., Jr., S. W. Payne, E. E. Recker, and R. J. Reed, 1979: Structure and properties of synoptic-scale wave disturbances in the intertropical convergence zone of the eastern Atlantic. J. Atmos. Sci., 36, 53-72.

Thorncroft, C. D., and B. J. Hoskins, 1994a: An idealized study of African easterly waves. I: A linear view. Quart. J. Roy. Meteor. Soc., 120, 953-982.

— waves. II: A nonlinear view. Quart. J. Roy. Meteor. Soc., 120, 983-1015.

Wang, C.-C., and G. Magnusdottir, 2005: ITCZ breakdown in three-dimensional flows. J. Atmos. Sci., 62, 1497-1512.

Webster, P. J., and H.-R. Chang, 1988: Equatorial energy accumulation and emanation regions: Impacts of a zonally varying basic state. J. Atmos. Sci., 45, 803-829.

Wheeler, M., and G. N. Kiladis, 1999: Convectively coupled equatorial waves: Analysis of clouds and temperature in the wavenumber-frequency domain. J. Atmos. Sci., 56, 374-399.

,-- , and P. J. Webster, 2000: Large-scale dynamical fields associated with convectively coupled equatorial waves. J. Atmos. Sci., 57, 613-640.

Yanai, M., T. Maruyama, T. Nitta, and Y. Hayashi, 1968: Power spectra of large-scale disturbances over the tropical Pacific. $J$. Meteor. Soc. Japan, 46, 308-323.

Zehnder, J. A., 1991: The interaction of planetary-scale tropical easterly waves with topography: A mechanism for the initiation of tropical cyclones. J. Atmos. Sci., 48, 1217-1230.

- D. M. Powell, and D. L. Ropp, 1999: The interaction of easterly waves, orography, and the intertropical convergence zone in the genesis of eastern Pacific tropical cyclones. Mon. Wea. Rev., 127, 1566-1585.

Zhang, C., 2005: Madden-Julian Oscillation. Rev. Geophys., 43, RG2003, doi:10.1029/2004RG000158.

Zipser, E. J., 1977: Mesoscale and convective-scale downdrafts as distinct components of squall-line structure. Mon. Wea. Rev., 105, 1568-1589. 